\title{
Arnavutluk Tarih Ders Kitaplarında Osmanl1/Türk İmgesi
}

\author{
Bülent Bilmez*
}

The Image of Ottomans/Turks in the History Schoolbooks in Albania

Abstract - This essay discusses the image of Ottomans/Turks in history schoolbooks in contemporary Albania, a country which was the first mainly Muslim nation-state to emerge from the Ottoman Empire. With an attempt to contextualize this discussion, it firstly summarizes the modern Albanian historiography and the institutions producing the historiographical discourses in Albania; secondly it depicts the narrower context of the production process of history schoolbooks and their use. The main corpus of the article is devoted, however, to a detailed analysis of history schoolbooks by focusing on several specific issues: a) The process of Ottomanization and Islamization in Albania and the place of Kosovo War (1389) in this process; b) the first phase (XIV-XV. centuries) of this process and the place of Skender beu's resistance against it; c) the socio-economic and cultural structure in the Classical Age (XVI-XVII. centuries); d) Albanians and Albania in the Ottoman modernization process (from 1830s to 1912); and finally e) the declaration of independence (1912) and its aftermath.

Keywords: Albania, History schoolbooks, Ottoman image, Turkish image, Imagology

Değişik anlatılarda karşımıza çıkan farklı gruplarla ilgili imgelerin incelenmesi anlamında 'imgebilim' (imagology) çalışmaları, maalesef Türkiye'de yeterince yaygın değil. Disiplinlerarası niteliğe sahip bu inceleme alanı, daha çok Kuzey Avrupa ülkelerinde, komşu ülke halklarıyla ilgili imgeler (imajlar) hakkında yapılan çalışmalara dayanmaktadır. ${ }^{1}$

* İstanbul Bilgi Üniversitesi.

1 Bu makale, TÜBİTAK 1001 projesi çerçevesinde Prof. Dr. Mehmet Hacısalihoğlu tarafindan yürütülen (110K571 nolu) "Balkan ve Karadeniz Ülkelerinde Güncel Tarih Ders Kitaplarında Osmanlı / Türk İmajı” başlıklı proje kapsamında hazırlanmıştır. 
Bu imgeleri barındıran önemli kaynakların başında gelen ders kitaplarındaki Osmanlı/Türk imgesiyle ilgili bu çalışmada, öncelikle meselenin kavramsal, teorik ve metodolojik boyutu ve bu alanda uluslararası düzlemde mevcut birikim kısaca ele alınacaktır. Çalışmanın ana gövdesini ise Arnavutluk'ta halihazırda kullanılmakta olan tarih ders kitaplarının detaylı analizi oluşturacaktır.

\section{Teorik, kavramsal ve metodolojik çerçeve}

Arnavutluk ders kitaplarında Osmanlı/Türk imgesinin eleştirel analizini yapmaya çalışacağım bu makalede, giriş mahiyetinde ve kısa da olsa imge ve analiz yöntemi konusunda bir açıklamanın zorunlu olduğunu düşünüyorum.

\section{İmge (imaj) ve imgebilim (imajoloji)}

Her şeyden önce, imgeden ve onun sistemli ve eleştirel incelenmesi anlamında imgebilimden bu çalışmada ne anlaşıldığ Bunu da imgenin ne olmadığı veya imgeden ne anlaşılmadığı üzerinden yapmak anlamlı görünüyor. Tarihyazımında bir olgunun imgesi bağlamında akla gelen ilk alternatif sözcük, bu olguyla ilgili tarihyazımındaki $\lg _{g}$ olmaktadır. Ayrıca, daha genelde bir olgunun tarihyazımındaki yerine veya o konudaki anlayışa baktığımızda da benzer şeyler yaptığımızı düşünürüz. ${ }^{2}$

Buna en güzel örnek, Oryantalizm/Şarkiyatçllık bağlamında, Batı'da Doğu/ Şark imgesi/algısı üzerine yapılan çalışmalardır. Edward Said'in, Osmanlı dünyasıyla ilgili algı ve imgeleri maalesef ihmal ederek, yayınladığı öncü çalışmasını ${ }^{3}$

2 Manfred Beller, "Perception, Image, Imagology", içinde Imagology: The Cultural Construction and Literary Representation of National Characters : a Critical Survey, ed. Joseph Theodoor Leerssen ve Manfred Beller (Rodopi Publications, 2007), 3-16; William L. Chew III, "What's in a National Stereotype? An Introduction to Imagology at the Threshold of the 21st Century", Language and Intercultural Communication 6, sayı 3-4 (2006): 179-87; Norman Friedman, “İmge”, Kitaplık, sayı 74 (2004): 80-88; Joep Leerssen, “Imagology: History and Method”, içinde Imagology: The Cultural Construction and Literary Representation of National Characters: A Critical Survey, ed. Manfred Beller ve Joep Leerssen (Amsterdam: Rodopi Publications, 2007), 17-32; C. Neil MacRae, Charles Stangor, ve Miles Hewstone, ed., Stereotypes and Stereotyping (New York: Guilford Press, 1996); Thomas W. J. Mitchell, Iconology: Image, Text, Ideology (Chicago: University of Chicago Press, 1986); Serhat Ulağl, İmgebilim “Öteki”nin Bilimine Giriş (Ankara: Sinemis Yayınlar1, 2006).

3 Edward W. Said, Şarkiyatçılık. Batı’nın Şark Anlayışları (İstanbul: Metis Yayınları, 2005). 
takip eden çalışmalarda, Osmanlı dünyası da kapsanarak genelde Doğu/Şark imgesi incelenirken, ${ }^{4}$ belli bir ülkenin tarihyazımında, edebiyatında veya genelde kolektif hafızasında Doğu, İslâm veya özel olarak Osmanlı ve/ya Türk imgesi konusunda değişik (seyahatname, edebiyat, karikatür, vd.) metinler eleştirel analize tabi tutulmuştur. ${ }^{5}$ Aynı şey Oksidentalizm/Garbiyatçılık bağlamında, Osmanlı'da veya genelde Doğu'da Garp/Batı imgesi/algısı konulu çalışmalar için de geçerlidir. ${ }^{6}$ Osmanlı/Türkiye edebiyatı bağlamında sadece ülke dışındaki 'öteki'lerle ilgili değil, ${ }^{7}$ ülke içindeki ötekilerle ilgili imgeler de çalışılmaktadır. ${ }^{8}$

Kuzey Avrupa ülkelerindeki çalışmalar başta olmak üzere, imgebilim çalışmalarında, komşu ülke halklarıyla ilgili stereotip ve klişeler incelenmektedir. ${ }^{9}$

4 Vasili Vladimiroviç Barthold, Rusya ve Avrupa'da Oryantalizm, çev. Kaya Bayraktar ve Ayşe Meral (İstanbul: Küre Yayınları, 2004); Rana Kabbani, Europe's Myths of Orient. Devise and Rule (London: Pandora Pres, 1986); Yüksel Kanar, Batı’nın Doğu'su (Avrupa’nın Barbarliğının Küreselleşmesi) (İstanbul: Kitabevi, 2006); Jale Parla, Efendilik, Şarkiyatçılık, Kölelik (İstanbul: İletişim Yayınları, 2005); Fuat Keyman, Mahmut Mutman, ve Meyda Yeğenoğlu, Oryantalizm, Hegemonya ve Kültürel Fark (İstanbul: İletişim Yayınları, 1996).

5 Fikret Adanır, "Wandlungen des deutschen Türkeibildes in der ersten Hälfte des 20. Jahrhunderts", Zeitschrift für Türkeistudien 4, say1 2 (1991): 195-211; Nazan Aksoy, Rönesans Ingilterésinde Türkler (İstanbul: İstanbul Bilgi Üniversitesi Yayınları, 2004); Necmettin Alkan, Avrupa Karikatürlerinde II. Abdülhamit ve Osmanlı İmajı (İstanbul: Selis Kitapları, 2006); Hasan Serkan Kırca, "İngiliz Seyyah Sir Charles Fellows'un Eserlerinde Türkiye ve Türk İmajı” (Yayınlanmamış Yüksek Lisans Tezi, 2010); Onur Bilge Kula, Alman Kültüründe Türk Imgesi, c. 1 (Ankara: Gündoğan Yayınları, 1992); Onur Bilge Kula, Alman Kültüründe Türk Imgesi, c. 2 (Ankara: Gündoğan Yayınları, 1992); Onur Bilge Kula, Batı Düşününde Türk ve İslâm İmgesi (İstanbul: Büke Yayınları, 2002); Süleyman Yıldız, “Türk ve Alman Toplumlarında Kültürel İlişkiler, İmgeler ve Medya”, Milli Folklor 18 (2006): 37-46.

6 Ian Bruma ve Avishai Margalit, Garbiyatçılık - Düşmanlarının Gözünde Batı (Istanbul: YKY, 2009); İbrahim Şirin, Osmanlı İmgeleminde Avrupa (İstanbul: Lotus, 2009); Baki Aslitürk, Osmanlı Seyyablarının Gözüyle Avrupa (İstanbul: Kaknüs Yayınları, 2000).

7 Herkül Milas, Türk Romanı ve "Öteki”. Ulusal Kimlikte Yunan İmajı (İstanbul: Sabancı Üniversitesi, 2000).

8 Müslüm Yücel, Osmanlı-Türk Romanında Kürt İmgesi (İstanbul: Agora, 2011); Ömer Solak, Romanda Öteki / Ötekinin Romanı. Osmanl Romanında Yabancılar ve Azınlıklar (Konya: Tablet Yayınları, 2008).

9 Manfred Beller ve Joep Leerssen, ed., Imagology: The Cultural Construction and Literary Representation of National Characters: A Critical Survey (Amsterdam: Rodopi Publications, 2007); Beller, "Perception, Image, Imagology"; Chew III, "What's in a National Stereotype? An Introduction to Imagology at the Threshold of the 21st Century"; Leerssen, "Imagology: History and Method". Stereotip üretim süreçleriyle ilgili bkz. MacRae, Stangor, ve Hewstone, Stereotypes and Stereotyping. 
Farklı ülke halklarının birbirleri hakkındaki (bazen somut ve sahici nedenlere dayansa da çoğu zaman kolektif hafızadaki mitlere dayalı) algılarını incelemek için bakılan kaynaklar akademik çalışmalardan medyadaki popüler metinlere kadar değişebilmektedir. Aslında herhangi bir imgenin toplumsal/popüler hafızadaki yerinin incelenmesi için bakılacak kaynakların çeşitliği de şaşırtıcıdır: Akademik ve popüler tarihyazımı, edebiyat, basın/medya, sözlü gelenek, müzik, maddi kültür objeleri, karikatür, resim, ikonografi, ders kitapları, vd. Bu anlamda, algı ve imge çalışmalarında karşılaşılan en temel metodolojik sorunlardan bir tanesi, bu imgeleri ararken kullanılan metinlerin (akademik ve popüler tarihyazımı, basın, ders kitapları, vs.) çeşitliliği ve bunların hepsinin kolektif hafızada imgelerin oluşum ve yeniden-üretim sürecindeki farklı rollerinin bulunmasıdır. ${ }^{10}$ Bunu incelemenin bir yolu da elbette anket veya farklı saha çalışması aracıllığıla doğrudan

10 Yıllar önce yayınlanan 'Amerikan basınında (1918-1923) Kurtuluş Savaş’' konulu makalelerimde (Bülent Bilmez, “Amerikan Basınında Türk Kurtuluş Savaşı”, Toplumsal Tarih 92 (2001): 1826; Bülent Bilmez, "Amerikan Karikatürlerinde Kurtuluş Savaşı”, Toplumsal Tarih 96 (2001): 29-36; Bülent Bilmez, "The Place of the Eastern Question and the Turkish Independence War in the American Press (1918-1923)", Turkish Yearbook of International Relations 2000/2, say1 31 (Special Issue on Turkish-American Relations) (2000): 51-74.) belli bir olguyla ilgili basındaki algı üzerine çalışmışıım. Daha sonra Türkiye ve Arnavutluk'ta farklı isimler ile anılan ve hakkında bir birinden farklı imgeler mevcut olan önemli bir şahsiyet olan Şemsettin Sami Frashëri'nin Arnavutluk tarihyazımındaki 'mitleştirilmiş' imgesini eleştirel okumaya tabi tutmayı denediğim çalışmalarımda (Bülent Bilmez, "Mythologization of an Ottoman Intellectual in the Modern Turkish and Socialist Albanian Historiographies based on 'selective perception': Sami Frashëri or Şemseddin Sami Bey”, Balkanologie. Revue d'études pluridisciplinaires VII, sayı 2 (2003): 1946; Bülent Bilmez, "Sami Frashëri apo Shemseddin Sami?", çev. Artan Puto, Përpjekja IX, sayı 18 (2003): 118-45; Bülent Bilmez, "Arnavut ve Türk Tarih yazımında Şemsedin Sami: Arnavut Milliyetçisi mi, yoksa Türk Milliyetçisi mi?”, Toplumsal Tarih 114 (2003): 54-57; Bülent Bilmez, "Modern Türkiye ve Sosyalist Arnavutluk Basınında Şemseddin Sami Frashëri İmajı”, içinde Balkanlarda İslàm Medeniyeti, II. Milletlerarası Sempozyumu Tebliğleri, (İstanbul: IRCICA, 2006), 71-125; Bülent Bilmez, "Şemsettin Sami ve 'Sakıncalı' bir Kitapla ilgili Tartışmalarda Milliyetçi Retorik”, Müteferrika 29, sayı 1 (2006): 45-87.) karşıma çeşitli metodolojik sorunlar çıtı. Aynı şey, 'tarihyazımında I. Meşrutiyet'in yeri' ile ilgili makalem (Bülent Bilmez, "Kosova ve Arnavutluk Tarihyazımlarında I. Meşrutiyet (1876-1878)”, içinde Güneydoğu Avrupa ve Balkanlar'da Osmanlı Tarih Araştırmaları ve Tarih Yazıcılı̆̆. Seminer Bildirleri (12 Temmuz 2008), ed. Halit Eren (İstanbul: Balkan Medeniyetleri Merkezi, 2010), 41-116.) ve 'Türkiye tarihyazımında İskender Bey imgesi' ile ilgili (Bülent Bilmez, "Skanderbeg in the Turkish Historiography: An attempt towards a critical assessment", içinde The Living Skanderbeg. The Albanian Hero between Myth and History, ed. Monica Genesin, Joachim Matzinger, ve Giancarlo Vallone (Hamburg: Verlag Dr. Kovaç (ORBIS - Wissenschaftliche Schriften zur Landeskunde Band 16), 2010), 185-222.) çalışmam için de geçerlidir. 
insanların kolektif hafızasını incelemek olabilir. Ders kitapları, bu konuda en önemli metin bütünlüğünü oluşturmaktadır.

Ulus-inşa sürecinde önemli rol oynayan ders kitaplarının, bir ülkede tarihçiler tarafından üretilmiş anlatı, algı ve imgeleri yaymada en etkili araç olduğunu söylemek yanlış olmayacaktır. Ülkenin her köşesinde geniş kitlelere erişim olanağı sunan medya (özellikle TV ve İnternet), bugün ders kitaplarıyla nispeten yarışabilir; ancak sistemli olması ve kurumsal çerçevesi ile ders kitapları (ve genelde zorunlu örgün eğitim) yine de daha dolaysız ve etkili bir araç olmayı sürdürmektedir. ${ }^{11}$

Herhangi bir olay, dönem, kurum, imge veya genelde bir mesele üzerine ders kitapları üzerinden çalıştığımızda, herhangi bir ülkede ulus-devlet anlatısının (resmî tarihin) en basitleştirilmiş ve kısaltılmışş şeklini bunlarda bulacağımızı ve bunun önemli bir kolaylaştırıcı unsur olduğunu düşünürüz. Ancak toplumsal/ kolektif hafızanın oluşmasında gerçekten önemli bir rol oynayan ders kitaplarının analizi söz konusu olduğunda akla hemen gelen bu 'avantaj'a eşlik eden bazı önemli dezavantajların veya potansiyel zaafların da söz konusu olduğunu, konu üzerine çalıştıkça daha çok görürüz: Tam da basitleştirme ve kısaltma nedeniyle birçok ayrıntı ve bu anlatının üretilme süreci ile yayılma yolları/yöntemleri ihmal edilebilmektedir. ${ }^{12}$ Ders kitaplarının işlevi, orijinal tarih bilgisi/anlatısı ortaya

11 Ders kitaplarının bu rolüyle ilgili eleştirel bir çalışma için bkz. Mustafa Çapar, Türkiyéde Eğitim ve Öteki Türkler, Özgür Üniversite Kitaplığı (Ankara: Maki Basın Yayın, 2006). Eleştirellikten uzak bir çalışma için bkz. A. Kadir Paksoy, Ulus Devlet ve Tarih Ĕğitimi (Ankara: Öğretmen Dünyası, 2008). Genelde tarih eğitimi ve ders kitaplarının modern toplum ve birey sürecinde araç olarak kullanımı için bkz. İbrahim Güler, Tarihin Toplumdaki İslevi ve Öğretimi (İstanbul: Elif Kitabevi, 2005).

12 Stuart Foster, "Dominant Traditions in International Textbook Research and Revision", Education Inquiry 2, sayı 1 (March) (2011): 5-20; Antoon De Baets, "Profile of the History Textbook Author as a Mediator between Historiography and Society", Internationale Schulbuchforschung 16, sayı 4 (1994): 515-34; Marc Ferro, The Use and Abuse of History or How the Past Is Taught to Children (London; New York: Routledge, 2003); William E. Marsden, The School Textbook. Geography, History and Social Studies (London \& Portland: Woburn Press, 2001); C. F. Strong, History in the Secondary School (London: University of London Press, 1964); J. D. Gasanabo, Fostering Peaceful Co-existence Through Analysis and Revision of History Curricula and Textbooks in South East Europe (UNESCO, 2006); Christina Koulouri, ed., Teaching the history of Southeastern Europe (Thessaloniki: Center for Democracy and Reconciliation in Southeast Europe, 2001); Christina Koulouri, ed., Clio in the Balkans: The Politics of History Education (Thessaloniki: Center for Democracy and Reconciliation in Southeast Europe, 2002); Robert Stradling, 20. Yüzynl Tarihi Nasıl Ögrretilmeli (İstanbul: Türkiye Ekonomik ve Toplumsal Tarih Vakfı, 2003); N. Barbarosoğlu, 
çıkarmaktan ziyade daha önce üretilmiş olan anlatıların yaygınlaştırılması/içselleştirilmesi ve popüler tüketim için bu anlatıların yeniden üretimidir.

İçerik/ söylem analizi için ele alınan 'metin'ler olarak ders kitaplarının, elbette onu önceleyen ve kapsayan üretim sürecinden (tarihyazımından) bağımsız gerçekleştirilince ve bu geniş bağlamdan kopuk olduğu oranda, analizin zayıf/ sorunlu olacağı bir gerçektir. Ancak popüler ve akademik tarihyazımından basına, maddi kültürden edebiyata, sözlü gelenekten müziğe kadar çeşitli düzlemlere sahip bu geniş bağlamın hakkıyla ele alınması da bu çalışmanın kısıtlı sınırları içerisinde neredeyse olanaksızdır.

Herhangi bir olgunun ders kitaplarındaki yerini incelerken diyalektik yaklaşım, ondan önceki süreci ve bu bağlamda farklı dönemlerde tarih ders kitaplarındaki değişimi de dikkate almayı gerektirir. Bu makale, içinde bulunduğu farklı siyasi durumların resmî anlatılarının karşılaştırılması ya da bir dönemselleştirme içerisinde Arnavutluk ders kitaplarının analizi gibi daha geniş bir çalışmaya temel oluşturmak adına günümüz ders kitaplarıyla sınırlı tutulacaktır.

\section{Ders kitaplarının kullanımı ve etkisi}

İmgelerin yaygınlaştırılması konusunda veya herhangi bir alanda ders kitaplarının gerçek etkisini incelemek için dar anlamda 'metin analizi' yeterli değildir. Öğrencilerin kullanımı için hazırlanan ders kitapları, dili ve görselleriyle çocukların hafızalarında derin izler bırakmakla birlikte; sınıf dinamiği ve merkezi pedagojik ve ideolojik çerçeve içinde hareket etme durumundaki ders öğretmeninin rolü ve kullanılan yöntem ile ek/yardımcı kaynaklar ve sonuçta bu metinlerdeki anlatıların öğrenciler tarafından alımlanması (reception) meselesi dikkate alınmadan yapılacak analizler her zaman eksik olacaktır. Üstelik oldukça sistematik ve çoğu zaman katı bir yapısal çerçeve (eğitim sistemi ve okul) içinde kullanılan bu kitapların sınıfta kullanımı konusunda Eğitim Bakanlığı̀nın veya yetkili biriminin yönetmelikleri ve yönergeleri de çok önemlidir. Nihai olarak analize katılması

ed., Tarih Öğretiminde Çoğulcu ve Hoşgörülü Bir Yaklaşıma Doğru (İstanbul: Türkiye Ekonomik ve Toplumsal Tarih Vakfi, 2003); Nurettin Elhüseyni, çev., Tarihin Kötüye Kullanımı (İstanbul: Türkiye Ekonomik ve Toplumsal Tarih Vakfi, 2003); Falk Pingel, Ders Kitaplarının Araştırma ve Düzeltme Rehberi (İstanbul: Türkiye Ekonomik ve Toplumsal Tarih Vakfi, 2003).Üç Batı ülkesinin (ABD, Britanya ve Almanya) ders kitaplarıyla ilgili karşılaştırmalı bir inceleme için bkz. Volker R. Berghahn ve Hanna Schissler, ed., Perceptions of History: International Textbook Research on Britain, Germany, and the United States (New York: Berg Publications, 1987). 
gereken boyut, sınıf içi uygulamalardır ki, bunun için de saha çalışması yapılmasının (yasal ve hukuki) zorlukları açıktır. Bu eksiklikleri bir miktar telafi için, ayrıca ders kitaplarının yaygınlaştırdığı imgelerin ne kadar etkili olduğunu görmek açısından okul içi ve dışında anketler yapmak mümkündür.

Son yıllarda Arnavutluk eğitim sistemi ve ders kitapları üzerine çalışmaların sayısı giderek artarken, ders kitaplarında Osmanlı/Türk algısı ve imgesi konusunda yeterince çalışma bulunmamaktadır. ${ }^{13}$

\section{Kaynaklar ve bağlam üzerine}

\section{Arnavutluk'ta tarihçilik: Üretim süreci ve üreticiler (aktörler/kurumlar)}

Arnavutluk tarihyazımında Osmanlı'nın yeri ve anlatımı ülkenin farklı rejim deneyimlerinde süreklilik göstermiştir. Osmanlı’nın son dönemlerinde Arnavut ulusçuluğu bağlamında başlayan 'milli' tarihyazımı süreci, Osmanlı'dan kopuş fikrini içerdiği için, Osmanlı imgesi her zaman problemli olagelmiştir. Özellikle Sosyalizm döneminde Tarih Enstitüsü ${ }^{14}$ yoluyla hem Anti-faşist Kurtuluş Savaşı

13 Bu konuda istisnai iki örnek için bkz. Denisa Kostovicova, "The Portrayal of the Yoke: The Ottomans and Their Rule in the Post-1990 Albanian-Language History Textbooks", Internationale Schulbuchforschung 24, say1 2 (2002): 257-78; Jazexhi Olsi, "Depicting the Other: the Image of the Muslim and the Turk in Albania's High School Textbooks", International Journal of Turkish Studies, Madison, Wisconsin ??, 15, sayı 1-2 (2009). Genelde tarihyazımında Osmanlı/Türk imgesiyle ilgili olarak bkz. Artan Puto, "Some Aspects of the Perception of the Ottoman period in the Albanian historiography”, 2002. Ayrıca genelde Balkan ders kitaplarında Osmanlı/Türk imgesi için bkz. Spyros Spyrou, "Constructing 'the Turk' as an Enemy: The Complexity of Stereotypes in Children's Everyday Worlds”, South European Society and Politics 11, sayı 1 (2006): 95-110. Hırvatistan örneği için bkz. Mırna Zunıć, "Hırvatistan'da Tarih Ders Kitaplarında Osmanlı İmajı” (Yüksek Lisans Tezi, Yıldız Teknik Üniversitesi, Siyaset Bilimi ve Uluslararası İlişkiler Ana Bilim Dalı, 2008). Bosna örneği için bkz. Ahmet Alibațić, "Images of the Ottomans in History Textbooks in Bosnia and Herzegovina”, İslâm Araştırmaları Dergisi 17 (2007): 103-37. Doğu ve Orta Avrupa ders kitaplarında Osmanlı/Türk imgesi konulu bir makale için bkz. Gabriel Pricky, "Çek Cumhuriyeti, Macaristan, Polonya ve Slovakya’dan lise ders kitapları aracilığıyla Doğu-Orta Avrupa'da Osmanlı dönemi”, Tarih ve Toplum, sayı 15 (Güz 2012).

141957 yılında Tiran Üniversitesi'nin bünyesinde çalışmaya başlayan 'Tarih ve Dil Enstitüsü’ndeki (Androkli Kostallari ve Lloshi Xhevat, "Instituti i Historisë dhe i Gjuhësisë", ed. Aleks Buda, Fjalori Enciklopedik Shqiptar (Tiranë: Akademia e Shkencave e RPSSH, 1985), 419.) Tarih Seksiyonu, enstitünün Bilimler Akademisi çatısı altında yeniden yapılandırılmasından sonra, bağımsız olarak Tarih Enstitüsü adıyla varlığını sürdürdü. 
vurgusu hem de ulusal bir tarih yazma çabası ile Osmanlı'ya karşı Arnavut isyanları vurgulanıyor ve ulusal bilinç bu yolla konsolide ediliyordu. Özellikle ortak bir ulusal bilinç yaratma ve bunu geliştirme anlamında Arnavut dili, edebiyatı üzerine Arnavut aydınların farkındalık kazanması ve bu alanda çalışmalar üretmesi yine Osmanlı aydınları ile ortak bir üretimin kaçınılmaz olduğu Osmanlı'nın son elli yıllık dönemine denk gelir. Ancak bu süreç, Dil ve Edebiyat Enstitüsü ${ }^{15}$ aracılığıyla, Osmanlı düşün tarihinden kopuk olarak anlatılmaktadır.

Arnavutluk'ta tarihyazımının ilk olarak kurumsallaşması ve bilimsel çalışmaların düzenli bir şekilde yayımlanmaya başlaması 1945-1991 yılları arasındaki sosyalist döneme tekabül etmektedir. Diğer birçok sosyalist devlet yapılanmasında görülebileceği üzere, Arnavutluk'ta da bu kurumsallaşma süreci enstitüler aracıllğıyla kurulabilmiştir. Tiran'daki üniversite ile birlikte bütün bu araştırma enstitüleri bir araya getirilerek 1972 yılında Arnavutluk Bilimler Akademisi (Akademia Shkencave e Shperisë) ${ }^{16}$ kurulmuştur.

İlk yıllardan itibaren 'yeni insan' ve 'yeni toplum' yaratma (yani aslında total ve radikal bir modernleşme) amacı güden rejim, bu amacına ulaşmak için gerekli epistemolojik dönüşümü, bu merkezi kurum üzerinden yürütürken, aslında en çok Arnavut ulusunun inşa sürecini tamamlama misyonunu yerine getirmekteydi. Diğer birçok amacının yanında, belki de en çok 'başarılı' olduğu konu da bu olmuş; devraldığı heterojen toplumdaki farklılıkları kısa sürede törpülenmiş, bu toplumu tek-tipleştirilmiş modern bir ulusa dönüştürmüştür.

1990lı yllara gelindiğinde, Akademi'de konumuzla ilgili alanlardan sorumlu Sosyal Bilimler seksiyonunun çatısı altında yukarıda bahsi geçen iki enstitü ve iki merkez mevcuttu. ${ }^{17}$ Arnavutluk'ta akademik tarihyazımının en önemli kurum-

151955 yılında Tarih ve Dil Enstitüsü (Insititu i historisë dhe Gjuhësise) adıyla bağımsızlaşan kurum içinde yer alan on 'bilimsel sektör'ün içinde sonraki Dil ve Edebiyat Enstitüsü’nün (Instituti i Gjuhësise dhe i Letërsisë) ilk nüveleri oluşturmuştur. (A.g.e.; Koço Bihiku, "Instiuti i Gjuhësisë dhe i Letërsisë", ed. Aleks Buda, Fjalori Enciklopedik Shqiptar (Tiranë: Akademia e Shkencave e RPSSH, 1985), 418.

16 Akademi'nin açılış toplantısı bizzat Enver Hoca’nın ve diğer önde gelen devlet adamlarının katılımıyla 25 Ocak 1973 tarihinde yapıldı ve Aleks Buda ilk başkan seçildi. (Xhevat Lloshi, ed., Academy of Sciences of Albania (Tirana: Publishing Council of the PSR of Albania, 1990), 6.) Başından beri akademiye verilen görev, resmî ideoloji olan Marksizm-Leninizm ve onun Enver Hoca yorumu temelinde bilginin üretimi ve yayılmasıydı. Böylece, iktisadi ve siyasi yaşamdaki tekelleşmeye paralel olarak, entelektüel ve kültürel yaşamda akademik bilgi üretme ve yayma tekeli de tek bir merkezi kuruma devredilmekteydi.

17 Luan Omari ve Anastas Dodi, “Akademia e Shkencave”, ed. Aleks Buda, Fjalori Enciklopedik 
larından ikisi olan Tarih Enstitüsü ${ }^{18}$ ile Dil ve Edebiyat Enstitüsü kuruldukları günden beri Osmanlı ve özellikle modern Osmanlı tarihiyle ilgili araştırmaların ve yayınların merkezi konumundaydı.

Modern Osmanlı tarihiyle ilgili çalışmalar yayınlayan diğer bir kurum da Eğitim ve Kültür Bakanlığı'na bağlı olarak çalışan Pedagojik İncelemeler Enstitüsü’dür (Instituti i Studimeve Pedagogjike). ${ }^{19} \mathrm{Bu}$ enstitünün 1989 yılında yayınladığı Tarih Terimleri Sözlüğü, okul öğrencilerine yönelik hazırlandığı için, modern Osmanlı tarihiyle ilgili genel bilgi ve tezlerin yayılması ve yerleşmesinde en etkili araçlardan olsa gerektir. ${ }^{20}$

Arnavutluk'ta Modern Osmanlı tarihiyle ilgili imgelerin (veya bilgilerin/algıların) 'sergi' yoluyla güçlendirilerek yeniden üretildiği ve yaygınlaştırıldığı ortamlardan biri olan müzeler ise kendilerine ait yayınlarıyla da bu görevi görmektedirler. $^{21}$

Sosyalizm sonrası dönemde diğer şehirlerde açlan üniversitelerde de tarih çalışmaları yapan bölümler mevcut olsa da, her zaman (ama özellikle sosyalist

Shqiptar (Tiranë: Akademia e Shkencave e RPSSH, 1985); Lloshi, Academy of Sciences of Albania, 8-22.

18 Stefanaq Pollo, "Instituti i Historisë", ed. Aleks Buda, Fjalori Enciklopedik Shqiptar (Tiranë: Akademia e Shkencave e RPSSH, 1985), 418.

19 Sotir Temo, "Instituti i Studimeve Pedagogjike", ed. Aleks Buda, Fjalori Enciklopedik Shqiptar (Tiranë: Akademia e Shkencave e RPSSH, 1985), 425.

20 Todi Dhama ve Vilson Kuri, Fjalor shpjegues i termave historike (Tiranë: 8 Nëntori, 1989).

21 Bu konuda başı çeken, Tiran'daki Ulusal Tarih Müzesi'dir (Muzeu Historik Kombëtar). (Kleanthi Dedi ve Sokrat Mosko, "Muzeu Historik Kombëtar", ed. Aleks Buda, Fjalori Enciklopedik Shqiptar (Tiranë: Akademia e Shkencave e RPSSH, 1985), 731; Stilian Adhami, Muzeologjia Shqiptare (Tiranë: Gervis, 2001), 51.) Bunun dışında Arnavutluk’un değişik şehirlerinde mevcut olan lokal müzelerden de modern Osmanlı tarihiyle ilgili olanlar mevcuttur. (Adhami, Muzeologjia Shqiptare.) Bunların başında, dönemin önde gelen şahsiyetleri adına açılan müze-evler gelmektedir. (A.g.e., 161-186; Bardhyl Graceni, "Shtëpia-muze e Kostandin Kristoforidhit”, ed. Aleks Buda, Fjalori Enciklopedik Shqiptar (Tiranë: Akademia e Shkencave e RPSSH, 1985); Xhyher Cani, "Shtëpia-muze e Luigj Gurakuqit", ed. Aleks Buda, Fjalori Enciklopedik Shqiptar (Tiranë: Akademia e Shkencave e RPSSH, 1985); Xhyher Cani, "Shtëpia-muze e e Migjenit", ed. Aleks Buda, Fjalori Enciklopedik Shqiptar (Tiranë: Akademia e Shkencave e RPSSH, 1985); Xhyher Cani, "Shtëpia-muze e Ndre Mjedës", ed. Aleks Buda, Fjalori Enciklopedik Shqiptar (Tiranë: Akademia e Shkencave e RPSSH, 1985).) Ayrıca Prizren Birliği’ nin yüzüncü yıldönümünde 1978 yılında açılan Arnavut Birliği İşkodra Şubesi Müze-evi de önemli merkezlerden biridir. (Cani Xhyher, "Shtëpiamuze e 'Dega e Lidhjes Shqiptare e Shkodrës", ed. Aleks Buda, Fjalori Enciklopedik Shqiptar (Tiranë: Akademia e Shkencave e RPSSH, 1985); Adhami, Muzeologjia Shqiptare, 172-173.) 
dönemde) ilk açılan üniversite olan Tiran Üniversitesi, akademik çalışmaların ve yayınların merkezi olmayı sürdürmüştür. ${ }^{22}$

Bu kurumlar ve onların yayınladığı metinler kadar önemli olan tarihçilerle ilgili olarak öncelikle şunları söylemek mümkündür: Çoğu ülkede akademik ve gayri-akademik olarak iki ayrı düzlemde karşımıza çıkan farklı kategorideki tarih yazıcıları, Arnavutluk'ta sosyalist dönemde aynı kişiler olmuştur. ${ }^{23} \mathrm{Bu}$ dönemde ayrıca 'popüler tarih yazıcısı' konumunda tarihçiler karşımıza çıkmamaktadır. Bu durum Arnavutluk'un küçüklüğü nedeniyle sosyalist dönemde bir konunun uzmanlarının sayısının az olmasının yanında, reel sosyalist ülkelerdeki merkezi(yetçi) yapının ve tek sesli resmî anlatının en abartılı versiyonlarından birinin burada mevcut olmasından da kaynaklanmaktadır.

\section{Arnavutluk'ta Resmî Tarih Anlatısı: Sürecin ürünleri/çıktıları}

Genelde Osmanlı ardılı ülkelerin tarihyazımlarında Osmanlı döneminin 'boyunduruk', 'baskı' vb. olumsuz sıfatlarla anıldığı bilinmektedir. Zaten modernist/gelişmeci paradigmadan bakılarak bölge halklarının gelişmesi/modernleşmesi önünde Osmanlı hakimiyetinin en büyük engel/pranga olduğu düşüncesi daha ulus inşa sürecindeyken üretilmiş ve bu sorunlu Osmanlı imgesi, ulus devletlerin üstlendiği ulus inşa sürecinin konsolidasyonu aşamasında en önemli araçlardan biri olan resmî/ulusal tarihyazımı tarafından sürekli yeniden üretilmiştir.

Balkan ulus devletlerindeki bu imgenin Arnavutluk'taki belki de en çarpıcı karşıllğını, ülkenin en önemli (klasik) Osmanlı tarihçilerinden Selami Pulaha’nın ifadelerinde görebiliyoruz. Pulaha’ya göre Arnavutluk'un "neredeyse yüzyıllık sert bir direnişten sonra” 15. yüzyılda Osmanlı hakimiyetine girmesi, "ülkenin

22 Shefik Osmani, “Universiteti i Tiranës 'Enver Hoxha”, ed. Aleks Buda, Fjalori Enciklopedik Shqiptar (Tiranë: Akademia e Shkencave e RPSSH, 1985), 1134-1135. Buna bir istisna oluşturan ve modern Osmanlı dönemiyle ilgili yazılara da yer veren Buletini Shkencor adlı dergiyi 1958 yılından itibaren yayınlayan İşkodra’daki iki yıllık Eğitim Yüksek Enstitüsü (Jup Kastrati, “'Buletini Shkencor' (1958)", ed. Aleks Buda, Fjalori Enciklopedik Shqiptar (Tiranë: Akademia e Shkencave e RPSSH, 1985).), 1957 yilında dilbilimci Jup Kasrati tarafından kurulmuştu.

23 Genel tarih ciltlerinde, monografilerde ve akademik süreli yayınlardaki makalelerde modern Osmanlı/Arnavut(luk) tarihiyle ilgili metinleri kaleme alan Stefanaq Pollo, Kristo Prifti, Kristaq Frashëri, Gazmend Shpuza ve Arben Puto gibi sosyalist dönemin önde gelen tarihçileri, aynı zamanda ansiklopedik sözlükteki ilgili maddeleri de kaleme alan yazarlardır. (Bülent Bilmez, "Arnavutluk'ta Osmanlı Tarih Araştırmaları ve Tarihyazımında Modern Osmanlı", Tarih ve Toplum Yeni Yaklaşımlar 9 (2009): 157-213) 
özgürlük ve bağımsızlığının son bulması” anlamına geliyordu. Ardından gelen yüzyıllarda büyük zorluklar yaşayan Arnavutluk'un gelişimini durduran Osmanlı yönetimi, Arnavutluk'a "gerileme ve durgunluk" getirmişti. ${ }^{24}$

Arnavut tarihyazıcılı̆̆ında Osmanlı imgesi ile ilgili genel eğilimlere baktığımızda, anakronik bir bakışla tarihin başlangıcından bugüne sürekli var olmuş bir Arnavutluk tasviri ve Osmanlı'da yaşanan olaylara Arnavutluk merkezli bir bakış açısı, aksi halde görmezden gelme tavrı ulusçu tarih yazımının bir parçası olarak sürekli devam edegelmiştir. Bu çalışmadaki amaçlarımdan biri de özellikle modern Osmanlı tarihi bağlamında tam da bu devamlılığın altını çizmekti. Farklı dönemlerde farklı rejimler ve ideolojilerin hakim olduğu Arnavutluk'ta değişmeyen bu milliyetçi anlatı, sosyalizm sonrası dönemde de neredeyse aynen devam etmiştir. $^{25}$

Kaba modernizm anlayışıyla sosyalist rejimin önceki döneme ait olarak yargıladığı kapitalist ve pre-kapitalist değerlerin temsilcisi de Osmanlı idi; sosyalist döneme dair her şeyin reddedildiği 1991 sonrası Arnavutluk da aynı modernist/ ulusçu paradigma içinde kalarak Osmanlıyı yine bu şekilde tahkim etmiştir. ${ }^{26} \mathrm{Bu}$ bağlamda, Arnavutluk'un bağımsızlığı sonrası gelişmelerle ilgili özgün çalışmalara rastlanmadığ gibi genel tarih kitaplarında da bu konunun tamamen ihmal edildiğini görüyoruz.

Günümüz tarih ders kitaplarını incelerken, konuyla ilgili geniş bağlamı sunmak üzere Arnavutluk'ta 1990'lar sonrası tarihçilik ve tarihyazımı dikkate alınmalıdır. Ancak yukarıda özetlenen sosyalist dönem tarihçiliği sonraki dönemde gerçek anlamda bir değişikliğe uğramadığı için bu çalışmada ele alınan (ilk baskıları 2000'li yıllarda yapılan) 2010’lu yılların ders kitapları da sosyalist dönemin tarihçiliğinin dolaysız ürünleridir. Bu sadece ders kitaplarının içeriği (konular, dönemler, şahsiyetler, vs.) ve egemen tarih anlayışı için değil, akademik tarihyazımı ve ders kitaplarının yazarları için de büyük oranda geçerlidir.

24 Selami Pulaha, "Wissenschaftliche Forschungen Über Die Osmanische Periode Des Mittelalters in Albanien (15. Jahrundert Bis Anfang Des 19. Jahrhunderts)", içinde Südosteuropa-Jahrbuch, 19: Die Staaten Südosteuropas und die Osmanen, ed. Hans Georg Majer (München: SelbstVerlag Südosteuropa-Gesellschaft, 1989), 163.

25 Puto, "Some Aspects of the Perception of the Ottoman period in the Albanian historiography". 26 Valentina Duka, "Reflections on the Past in Albania in the 1990s", içinde (Re)Writing History - Historiography in Southeast Europe after Socialism, ed. Ulf Brunnbauer (Münster: LIT Verlag, 2004), 31-53. 
1990'lardan sonra genelde tarihyazımı konusunda gözlemlenen tek kayda değer değişiklik, Marksist-Leninist Avrupamerkezci terminolojinin yerini, liberal Avrupamerkezci söylemin almasıdır. Aynı değişikliğin gözlemlendiği ders kitaplarında özellikle format konusunda da (eğitim ve ders kitaplarıyla ilgili AB projeleri sayesinde) önemli farkların söz konusu olduğunu aşağıda göreceğiz. Sosyalist dönemde aslen ulus-inşa sürecinin en önemli araçlarından biri olarak kullanılmaktan öteye geçmeyen tarih anlayışı sonraki dönemde devam etmiştir. Tarihyazımı ve tarihin popüler kullanımı ve bunun aktörleri ile alandaki aktörler (üniversiteler, enstitüler, tarihçiler, müzeler, vs.) bağlamında bir kopuştan söz etmek mümkün değildir.

\section{Arnavutluk'ta tarih eğitimi ve ders kitapları}

Arnavutluk'ta tarih dersleri ${ }^{27}$ günümüzde, 2008 yılında gerçekleştirilen reform sonrası 'dokuz yıllık okul' (Shkolla 9-Vjeçare) olarak, ilköğretimin altıncı sınıfından itibaren verilmektedir. ${ }^{28}$ Önce dünya tarihinin ve ardından Arnavutların

27 Arnavutluk eğitim sistemi ve ders kitaplarıyla ilgili genel bilgi için bkz: Edlira Bitincka, "Përdorimi historisë në manualet e shkollës së mesme të përdorur në vitet 1974, 1995 and 1999”, Përpjekja 18 (2003): 69-83; Valentina Duka, "Albania [Educational System and History Teaching]", içinde Clio in the Balkans: The Politics of History Education, ed. Christina Koulouri (Thessaloniki: Center for Democracy and Reconciliation in Southeast Europe, 2002), 475-78; Erind Pajo, "Albanian Schoolsbooks in the Context of Societal Transformation: Review Notes", içinde Clio in the Balkans: The Politics of History Education, ed. Christina Koulouri (Thessaloniki: Center for Democracy and Reconciliation in Southeast Europe, 2002), 445-61; Dubravka Stojanovic, "Albanians and their Neighbours: the Future's Past", içinde Clio in the Balkans: The Politics of History Education, ed. Christina Koulouri (Thessaloniki: Center for Democracy and Reconciliation in Southeast Europe, 2002), 466-72; Robert Pichler, "Albania (in colboration with A. Ecker)", içinde How to Construct Civil Societies? Education, Human Rights and Media in Southeast Europe: A Critical Guide, ed. Ulf Brunbaauer vd. (Graz: Center for the Study of Balkan Societites and Cultures, 1999); Fatmira Myteberi, "Albania: Education for Peace, Stability and Democracy in Albania", içinde Education and Media in Southeast Europe: Country Reports, ed. Ulf Brunbaauer vd. (Graz: Center for the Study of Balkan Societites and Cultures, 1999); Daniel Fickenscher, "Das Schulwesen und die Schulbücher für die mazedonische Minderheit in Albanien”, Internationale Schulbuchforschung / International Textbook Research, , Zeitschrift des Georg-Eckert-Instituts 2, say1 23 (2001): 269-75; John I. Thomas, Education for Communism: School and State in the People's Republic of Albania (Stanford, California: Hoover Institution Press, 1969); Ira Metani, Transforming Education: The Albanian Experience (New York: Nova Science Publishers, Inc., 2003); Dieter Nehring, "Geschichtsbücher in Albanischsprachigen Gebieten Südosteuropas”, Eckert. Working Papers?, sayı 3 (2014).

28 İlköğretim dördüncü sınıfta hayat bilgisi düzeyinde verilen tarih dersi ile ders kitabı ve değişik materyaller kullanılarak beşinci sınıfta ders kitabı olmadan işlenen 'yerel tarih' konulu dersler dikkate alınmamıştır. 
tarihinin anlatıldığı 1 6-12. sınıflar arasındaki ders kitaplarının kapsadığı zaman ve mekanları şöyle özetleyebiliriz:29 'Tarih' (Historia [Për klasën e 6-të të shkollës 9-Vję̧are]) başlıklı altıncı sınıf tarih ders kitabında (6. sınıf DK) Rönesans'a kadar dünya tarihi anlatılırken; yine 'Tarih' (Historia [Për klasën e 7-të të shkollës 9-Vjeçare) başlıklı yedinci sınıf tarih ders kitabında (7. sınıf DK) ise (Geç Rönesans'tan 19. yüzyıl sonuna kadar) modern dünya tarihi anlatılmaktadır. 'Tarih' (Historia [Për klasën e 8-të të shkollës 9-Vję̧are]) başlıklı sekizinci sinıf tarih ders kitabında (8. sınıf DK) 20. yüzyıl dünya tarihi anlatılırken; ilköğretimin 'Tarih' (Historia) başlıklı dokuzuncu sınıf (yani ilköğretim son sınıf) ders kitabında (9. sınıf DK) başlangıçtan bugüne Arnavutların tarihi işlenmektedir. Yani ilköğretimin son dört yılında, önce (altıncı sınıf) başlangıcından XVI. yüzyıla modern öncesi dönem ve sonra (yedinci sınıf) XVI.-XIX. yüzyllar arası modern dönem anlatıldıktan sonra, ertesi yıl (sekizinci sınıf) XX. yüzyıl Dünya tarihi anlatılmaktadır. İlköğretimin son sınıfı olan dokuzuncu sınıfta ise, Arnavut tarihinin aynı yüzyıllarla ilgili kısmı anlatılmaktadır. On birinci sınıfta okutulan tarih ders kitabında (11. sınıf DK) genel modern dünya tarihi (Hümanizm ve Rönesans'tan 2000 yılına kadar dünya tarihi) okutulmaktadır. Ancak önceki yılların genel tarih ders kitaplarından farklı olarak, bu yılın tarih ders kitabı 'Dünya Medeniyetleri Tarihi' (Historia e qytetërimit botëror) başlı̆ııı taşımaktadır. Nihayet on ikinci sınıf ders kitabı (12. sınıf DK) ise ilköğretimin son yılı olan dokuzuncu sınıf ders kitabında olduğu gibi, tamamen Arnavut tarihine ayrılmışırı. Ancak sadece 'Tarih' başlığını taşıyan dokuzuncu sınıf ders kitabında söz konusu tematik odak belirtilmezken, “Tarihöncesi (100.000 ile 3.000 yıl öncesi)" nden 2010 yılına kadar Arnavutların tarihinin anlatıldığı on ikinci sınıf tarih ders kitabının başlığında bu açıkça belirtilmektedir: 'Arnavutların Tarihi' (Historia e shqiptarëve [Për klasën e 12-të shkollës mesme)). Yani ortaöğretimin ilk yılı olan onuncu sınıfta modern öncesi dönem işlenirken, on birinci sınıfta modern dönem, başlangıcından (XVI. yüzyıl) bugüne kadar işlenmektedir. Böylece, ilköğretimde üç yılda (altı, yedi ve sekizinci sınıfta) işlenen dünya tarihi, ortaöğretimde iki yılda (on ve on birinci sınıfta) işlenmektedir. Son sınıflarda ise başlangıcından bugüne Arnavutların tarihi işlenmektedir.

Anlaşılan, tarih eğitiminde hem ilköğretim hem de ortaöğretimde öğrencilerin ilk yıllarda (genel) dünya tarihi öğrenmeleri ve bunun ardından ilk ve orta öğretimin son sınıflarında 'kendi' tarihlerine yoğunlaşmaları hedeflenmektedir.

29 Makalenin sonundaki kaynakçada listesi bulunan bu ders kitaplarına (DK) yapılacak metin içindeki göndermelerde kısaca parantez içinde kitabın ait olduğu öğretim yılı ve ilgili sayfalar belirtilecektir. 
Bu yöntem üzerinden öğrencilerin 'kendilerinin' (ülkelerinin, kültürlerinin, vs.) tarihini, genel dünya tarihi içindeki yerinin bilincinde olarak (küresel perspektifle) 'okuması' amaçlanmış olabilir, ancak bu amaca ne kadar ulaşıldığının anlaşıması için Arnavut tarihine küresel ve/ya karşılaştırmalı bir bakışın mevcut olup olmadığına bakmak gerekmektedir ki, bu çalışmada amaçlanan şeylerden biri de budur.

Ders kitapları ünitelere/kısımlara ayrılmakta, (yedinci sınıftan itibaren) bu üniteler de bölümlere ayrılmaktadır. Her bölüm sadece birkaç (en fazla üç) sayfadan oluşmaktadır. Çoğu zaman çok kapsamlı meseleler bile kısa bir paragrafta ve bazen bir cümlede ele alınmaktadır. Bu nedenle, bu çalışmada içerik analizi yapacağım aşağıdaki bölümde, herhangi bir olgunun veya konunun anlatıldığı veya tartışıldığı söylendiğinde aslında kastedilenin 'değinmek' olduğu unutulmamalıdır. Ancak bu durum, kitapların zayıflıklarını göstermez. Bu metinlerin daha detaylı işlenecek (anlatılacak ve tartışılacak) konular için bir genel çerçeve sunduklarını düşünmek mümkündür. Bu nedenledir ki, bu kitapların sunduğu imge, algı ve bilgilerin alımlanması meselesi bizzat ders süreciyle ve özellikle (kendilerine sınıfta büyük inisiyatif verildiği ve önemli rol yüklenildiği anlaşılan) öğretmenlerin uygulaması ile birlikte anlaşılabilir.

İlköğretim tarih ders kitaplarında, her bölümün başında metinden önce bir kutu içinde konunun ana fikri birkaç cümleyle (dokuzuncu sınıfta birkaç tümceyle) çok kısa şekilde verilmektedir. Ortaöğretim tarih ders kitaplarının bölüm başlarında böyle kutu içinde özetler yoktur, ama onun yerine daha kapsamlı bir ön hazırlık çalışması vardır: On birinci sınıf tarih ders kitaplarının bölüm başlarında önce maddeler halinde bölümün "Hedefler"i veya "Amaçlar"1 sıralanmakta, daha sonra "Ana kavramlar" listesi ve çizgisel bir kronoloji tablosu ("Zaman") verilmektedir. Sonunda da ilgili bölümde geçen "Mekanlar" (11. Sınıf DK: 91) bulunmaktadır. Bölüm başlamadan verilen ön hazırlık tablosunun daha kapsamlı olduğu on ikinci sınıf ders kitaplarında, bu konuda on birinci sınıf ders kitaplarına göre iki fark görülür: "Mekanlar"a bu ön hazırlık tablosunda yer verilmezken, ilkinde ikinci sırada verilen "Temel Kavramlar", bu sefer "Anahtar Kavramlar" başlığıyla tablonun sonunda verilmektedir.

Bölüm sonlarına öğretilenleri test etmeyi ve öğrencileri yorum ve tartışmaya davet etmeyi amaçlayan sorular eklenmiştir. Boşluk doldurma, kare bulmaca, eşleştirme, konvansiyonel soru-cevapla bilgi testi gibi farklı yöntemlerle hazırlanmış bu bölümde, özellikle öğrencileri düşündürmeye ve yorum yaptırmaya yönelten 
sorular ilginçtir. Bu bölümde yer alan 'Sözlükçe’ ve 'Önemli Tarihler' kutucukları da zaten kısa olan bölümlerin daha kapsülleştirilmiş özetleri gibi durmaktadır.

Arnavutluk Eğitim ve Spor Bakanlığı tarafından hazırlanan ve 2012 yılında çıkan 69 no'lu kanun ${ }^{30}$ gereğince ders kitapları, bakanlığın belirlediği müfredat çerçevesinde farklı yayınevleri tarafından yayınlanmakta ve kitap seçimi okullara bırakılmaktadır. Bu çalışmamda, Arnavutluk'ta en yaygın şekilde kullanılan "Albas Okul Yayınları"nın (Botime Shkollore Albas) kitaplarını inceleyeceğim. Arnavutluk, Kosova ve Makedonya için Arnavutça ders kitapları yayınlamak üzere 2000 yılında kurulan ${ }^{31}$ Tiran'daki bu yayınevi tarafından renkli basılmış bu ders kitaplarının önemli bir özelliği, resim, harita, fotoğraf, grafik vb. görsellerin bolca kullanılmış olmasıdır. Kitabı daha kolay okunur hale getiren bu görsellerin oldukça iyi seçildiği söylenebilir, bazen hiçbir açılama eklenmeden verilen bu görsellerin bir çoğu farklı yılların ders kitaplarında tekrarlanmıştır.

Bu kitapların yazarlarına gelince, birden fazla yazar tarafindan kaleme alınan tüm bu ders kitapları aslında sadece beş tarihçi tarafından yazılmıştır: Tomi Treska, Menduh Dërguti, Sonila Boçi, Ledia Dushku ve Ferit Duka. Ancak bunlar arasında en tanınmış kıdemli tarihçi Duka sadece bir kitaba (on ikinci sınıf) katkı sunarken; Dushku ve Boçi ise iki kitaba (dokuzuncu ve on ikinci sınıf) katkı sunmuşlardır. Dërguti ve Treska’nın adları ise (farklı şekilde sıralanmak üzere) tüm kitapların üzerinde vardır. Diğer bir deyişle, son iki isim genel tarih kitaplarını tek başlarına; Arnavutların tarihi kitaplarını ise diğer iki isimden biriyle (dokuzuncu sınıf) veya ikisiyle (on ikinci sınıf) birlikte kaleme almışlardır.

\section{Söylem Analizi: Ders Kitaplarında Osmanlı/Türk İmajı}

Ders kitaplarının incelenmesi sırasında dikkat edilmesi gereken çok önemli bir olgu, 'Osmanlı', 'Türk' ve 'İslâm' kavramlarının genelde birbirleri yerine kullanılmasıdır. ${ }^{32}$ Kendi başına bir sorun olarak ele alınması gereken bu durum, genelde Oryantalizm tartı̧̧ması çerçevesi içinde tartışılabileceği gibi, bazen farkında bile olunmadan Osmanlı, Türk ve İslâm kavramlarının birbirleri yerine ikame edilmesinin, radikal modernist bir proje olarak karşımıza çıkan sosyalist Arnavutluk ana söyleminin devamı olduğu da unutulmamalıdır. Osmanlı son

30 Kostallari ve Xhevat, "Instituti i Historisë dhe i Gjuhësisë", 419.

31 http://sq.wikipedia.org/wiki/Albas

32 Bülent Bilmez, "Arnavutluk Ders kitaplarında Birinci Dünya Savaşı", 2011. 
döneminde modernist (proto) ulusçu Arnavut aydınların metinleriyle başlatabileceğimiz bu söylemin, bağımsızlık (1912) öncesi dönemde daha sentetik olduğunu ve "ait" olduğu dünyaya (doğu, İslâm, Osmanlı) henüz yabancılaşmadığını söylemek mümkündür. Burada dikkati çeken çelişki, tarihyazımında modernist söylemin hakimiyetine rağmen modern-öncesi Osmanlı'nın genelde modernleşen Osmanlı'ya tercih edilmesidir ki bunu, Şemsettin Sami Frasheri üzerine bir çalışmamda işlemiştim: Romantize edilen vahşi ama soylu 'geleneksel' Arnavut kültürünün yaşayabildiği modern-öncesi Osmanlı'da yaşanan görece özerk/bağımsız yaşamın, on dokuzuncu yüzyıl boyunca modernleşme (merkezileşme) sürecinde yitirilmesine duyulan tepki şeklinde ortaya çıkmaktadır bu çelişkili tavır. ${ }^{33}$ Bunun ders kitaplarında da karşımıza çıkıp çıkmadığına aşağıda bakacağız.

Yirminci yüzyılda bağımsız Arnavutluk'ta giderek 'doğu', 'İslâm' ve 'geçmiş/ gerilik' ile özdeşleştirilen Osmanl’dan kopma süreci, sosyalist dönemde sadece terminoloji bağlamında değişmiş ve 'feodal' Osmanlı'nın gelişmeye engel yapısı tekrarlanmış, rejimin tasfiye etmeye çalıştı̆̆ tüm 'eski' değer, kurum ve yapılar da Osmanlı'nın artığı olarak görülmüştür (Aynı şeyin diğer Osmanlı-sonrası Balkan ulus ülkelerinde veya ulus-devletlerinde olduğu gibi Türkiye Cumhuriyeti’nde de uzun süre mevcut olduğunu unutmamak gerekiyor...) Ders kitaplarına bu alg1nın nasıl yansıdığına bakacak olursak, genelde Osmanlı tarihinin farklı dönemlerinin özellikle öne çıkarıldığı ve her dönem için belli olgu, şahsiyet ve olaylara odaklanıldığı görülmektedir.

Okul öğrencilerinin ilk kez 'Osmanlı' ve 'Türk' kavramlarıyla karşılaştıkları, dünya tarihinin anlatıldığı altıncı sınıf ders kitaplarında, ilk olarak "Selçuklu Türkleri”nden söz edilirken, Orta Asya'dan gelip İslâm dünyasında büyük bir devlet kuran ve Türklerin bir kolu olan Osmanlıların tarihi de hemen ardından kuruluşu, gelişmesi ve özellikle Balkanlarda yayılma süreciyle birlikte anlatılmaktadır. (6. sinıf DK: 117-119)

Bu kitabın konuyla ilgili ilk bölümünde (Ders 57) Osmanlı öncesi dönem anlatılırken şunlar söylenir: 1050 yılından itibaren Bizans topraklarını istila etmeye I fethetmeye (pushtonin) başlayan Selçuklu Türkleri, Malazgirt (Manzikert) sonrası bugünkü Türkiye topraklarını ve ardından Suriye ve Filistin’i istila etmişler ve

33 Bilmez, "Arnavutluk'ta Osmanlı Tarih Araştırmaları ve Tarihyazımında Modern Osmanlı”; Bülent Bilmez, "Şemseddin Sami Farshëri’nin Bazı Metinlerde Arnavut ve Türk 'Biz’inin İnşasına Katkıda Bulunan Otoktonluk ve Köken Mitleri”, içinde Tanzimat ve Edebiyat ve Tanzimat, Osmanl İstanbulu’nda Modern Edebi Kültür, ed. Mehmet Fatih Uslu ve Fatih Altuğ (İstanbul: Türkiye İş Bankası Kültür Yayınları, 2014), 387-425. 
İslâm’ı benimseyerek yeni camilerin yapımına başlamışlardır. (s. 117) Anadolu’ya girişleri ve Ortadoğu’yu istila etmeleri ile İslâm'ı kabul etmeleri eş zamanlıymış gibi anlatılmaktadır; oysa Selçuklu Türkleri bundan çok daha önce İslâm’ kabul etmişlerdir. 1200'lü yıllarda küçük gruplara ayrılan ve rakip beyler ("prensler”) tarafından yönetilen Selçukluların topraklarının, 1300’lü yıllarda Moğol istilasına uğradığı ve Türkiye dışındaki toprakların istila edildiği belirtildikten (s. 117) sonra, "Osmanlı İmparatorluğu'nun doğuşu ve gelişmesi” başlığı ile başlayan sonraki bir paragraflık alt-bölümde, "1301 yllında Osman isimli bir bey [princ (prens)] kendisini tüm Türklerin sultanı (kralı) ilan etti” denilmekte ve toprakları giderek büyüyen Osmanlı İmparatorluğu'nun kuruluşu sırasındaki gücü vurgulanarak Osmanlı orduları övülmekte, hemen arkasından bu gücü kullanarak gösterdiği işgalcilikteki başarı dile getirilmektedir. Bu alt-bölümde Osmanlı ile ilgili dile getirilen olumlu özelliklerden biri de Osmanlıların halklarılla "sıkı bağ" kurması ve "şehirlerinde güzel camiler, okullar ve hamamlar yapması" dır. (s. 117) On birinci sınıf ders kitabında "Osmanlı İmparatorluğu’nun kökeni” başlıklı alt bölümde de aynı anlatı biraz daha detaylı olarak tekrarlanmakta (11. sınıf DK: 18-21); burada da Osmanlı́nın kuruluş yılının (genelde Türkiye tarihyazımında hakim olduğu üzere 1299 olarak değil) 1301 olarak verildiği görülmektedir. (s. 18 ve 21) İlginç bir şekilde, on ikinci sınıf tarih ders kitabında ise Osmanlı hanedanlığının kuruluş yılı olarak 1299 yılı verilmektedir. (s. 62) Arnavutların tarihinin anlatıldığı dokuzuncu (9. sınıf DK) ve on ikinci (12. sınıf DK) sınıflarda ise Osmanlı tarihi Balkanlarda yayılma sürecinden itibaren anlatılmaya başlanmakta, ondan öncesinden söz edilmemektedir.

\section{a) Osmanlı'nın Balkanlara girişi/yayılması ve Arnavutluk'ta Osmanlılaş(tır)ma ve Müslümanlaş(tır)ma süreci}

Genelde Arnavutluk'ta tarihyazımında olduğu gibi, Balkan ülkelerinin ders kitaplarında da Osmanlı ile ilgili asıl anlatı Osmanlı'nın Balkanlara giriş dönemiyle başlatılmaktadır ve bu dönemle ilgili anlatıların niceliksel ve niteliksel olarak tuttuğu yer, sıra dışı öneme sahiptir. ${ }^{34}$

Ders kitaplarında bu dönemle ilgili anlatılarda dikkati çeken şeylerin başında, yekpare bir bölge (ülke) olarak Arnavutluk ve onun halkı Arnavutların o sırada (her zaman olduğu gibi) mevcut olduğunu varsayma özcülüğ̈̈dür.

$34 \mathrm{Bu}$, genelde Balkan tarihyazımları için geçerlidir. (Alibațić, "Images of the Ottomans in History

Textbooks in Bosnia and Herzegovina”.) 
Osmanlı orduları Balkanlarda yayılmaya başladıklarında 'Arnavutluk' diye yekpare bir siyasi, kültürel, iktisadi ve hatta coğrafi birim mevcut olmadığı halde, “Osmanlı'nın Arnavutluk'ta yayılması"ndan söz edilebilmekte ve bölgede (bugünkü Arnavutluk topraklarında) Osmanlı yayılması adeta kesintisiz bir süreç olarak sunulmaktadır.

$\mathrm{Bu}$ anlatının doğal parçası olarak, tarih boyunca mevcut aynı halk olarak 'Arnavutlar' da yine özcü anlayışla sunulmaktadır. Buna ek olarak bazen bunun modern Arnavut ulusu ile eş anlamda kullanıldığı ve böylece önemli bir anakronizm hatasına düşüldüğü de görülmektedir (Aynı özcülük ve anakronizm sorununun 'Türk' kavramının kullanımında da karşımıza çıktığını aşağıda göreceğiz.) Burada ilk olarak sözü edilen 'Osmanlı' kavramı da ders kitaplarında özcü bir anlayışla ele alınmakta ve yönetimi, kültürü, ekonomisi vs. ile her zaman her yerde mevcut bir öze sahip bir olgu gibi anlatılmaktadır.

$\mathrm{Bu}$ dönemin anlatımıyla ilgili genel tespitlerimizden biri de, bölgedeki yayılma ve yerleşme sürecinin anlatımı sırasında, Osmanlı'nın modern anlamına yakın şekilde yabancı ve işgalci bir güç olarak resmedilmesidir. Oysa Osmanlı yayılmasında modern dönem deniz aşırı Batı sömürgecileri gibi, uzak bölgelerden aniden gelmiş işgalci sömürgecilerin hakimiyet (kısmi yerleşimi/kolonizasyonu da içeren bir yönetim) kurması değil; klasik imparatorluklarda olduğu gibi, teritoryal büyüme bağlamında komşu toprakların entegrasyonu ve içerimlenmesi (incorporation) söz konusudur. Ders kitaplarında bu yayılma ve yerleşme tarihi değişik aşamalardan ve hatta zikzaklardan oluşan diyalektik bir Osmanlılaş(tır) ma ve İslâmlaş(tır)ma süreci olarak anlatılmamakta; onun yerine aslında kendi içinde çelişkili bir anlatı tercih edilmektedir. Bir yandan adeta harita rengi değişir değişmez Osmanlı olmuş bir toprak parçası anlatısına yer verilirken, diğer taraftan da Osmanlı'dan farklı (yer yer bağımsız) bir tarihe sahip bir bölge olarak Arnavutluk ve onun hep mevcut olmuş Arnavut halkının tarihi anlatılmaktadır. Osmanlı́nın kim olduğu sorgulanmadığı için, Arnavutluk denen topraklarda yaşayan halkın Osmanlı kavramının içinde olup olmadığı da muğlak kalmaktadır. Ya da tersinden sorun şu şekilde de ortaya çıkmaktadır: Eğer Osmanlı'nın yayıldığı tüm topraklardaki halklar 'öteki' idiyse Osmanlı kimdi(r)? Ya da bu sorgulamanın yapılmaması nedeniyle Osmanlı çoğu zaman Türk ile eşanlamlı kullanılmaktadır, ancak (hem popüler kültür ve kolektif hafızada hem de Osmanlı dönemi aydınlarının anlatılarında) sonraki dönem Osmanlı yayılmasında ve diğer birçok başarıda imzası olan Osmanlı eliti ve hatta halkı olan Arnavut imgesi mevcuttur. 
Osmanlılaş(tır)ma süreci ile Müslümanlaş(tır)ma süreci aynı şey olmadığı ve birincisinin daha kapsamlı bir anlama sahip olduğu, yani İslâmlaş(tır)ma içermeyen bir Osmanlılaş(tır)ma sürecinin de söz konusu olduğunu unutmamak gerekiyor. Genelde 'Osmanlılaş(tır)ma” sürecinden, bir bölgenin iktisadi, sosyal ve kültürel anlamda (oldukça geniş, esnek ve muğlak) Osmanlı paradigmasına entegrasyonu anlaşılmalıdır ve bunun sembolleri/göstergeleri arasında nominal hakimiyet, tahrir, vergi toplama ve hatta (zamanla) sosyo-kültürel kodlar bulunsa da, Müslümanlaşma bulunmak zorunda değildir. Nitekim Osmanlılaştırılmış Balkanlarda Müslüman halkların sayısı Hıristiyan Osmanlılardan çok daha azdır. Müslümanlaş(tır)mayı da kapsayan Osmanlıla(tır)ma sürecinin (oldukça uzun ve çetrefilli bir süreç sonunda) yoğun olarak yaşandığı bölgeler olarak bugünkü Bosna ve Arnavutluk bu nedenle ayrı bir kategori olarak ele alınmayı hak etmektedir. Daha çok iskan politikaları ve kolonizasyon yöntemi sonucu kısmen Müslümanlaşma süreci yaşanan bugünkü Makedonya, Bulgaristan ve Kuzey Yunanistan toprakları ayrı bir kategori olarak alınabilir. Sonuçta modern döneme ağılıklı olarak Müslüman nüfusla giren Arnavutluk'ta bu Müslümanlaştırma sürecinin hemen Osmanlı yayılmasının başında ve kısa bir sürede gerçekleşmediği (özellikle Selami Pulaha ve Halil İnalcık'ın çalışmaları sayesinde) iyi bilinmektedir.

$\mathrm{Bu}$ süreçle ilgili anlatıda öne çıkan savaş, doğal olarak Kosova Savaşı'dır (1389). Aşağıda ayrı bir başlık altında ele alacağımız bu savaştan zaferle çıkan Osmanlı'nın Balkanlara yerleşme tarihi aynı zamanda Arnavut(luk) tarihinin de parçası olduğu için dünya tarihi ders kitaplarında vurgu artmakta, Arnavutların tarihi ders kitaplarında ise artık "tarihimiz" in parçası olarak sunulmaktadır.

$\mathrm{Bu}$ anlatıda Osmanlılaş(tır)ma sürecinin, yani Osmanlı'ya eklemlenme (entegrasyon) veya içerimlenme (incorporation) sürecinin ilk evresi çok kısa anlatılırken, bu sürece karşı sergilenen yerel direniş(ler) ve özellikle İskender Bey'in (Skenderbeu / Scanderbeg) çeyrek yüzyıllık (1443-1467) (6. sınıf DK: 125; 9. sınıf DK:32 ve 35$)^{35}$ direnişi özellikle öne çıkarılmakta ve bir 'ulusal kahraman' gibi sunularak direnişine, dönem tarihinde (hem niteliksel hem de niceliksel bağlamda) ayrıcalıklı yer ayrılmaktadır.

Dünya tarihinin parçası olarak altıncı sınıfta okutulan tarih kitabında ilk defa öğrencilerin karşısına çıkan Osmanlıların Balkanlarda yayılma anlatısına göre, Osmanlı neredeyse bir anda ve kesintisiz bir yayılma süreci sonunda

35 Bazı ders kitaplarında "25 yıllık" direnişten söz edilirken (6. sınıf DK:125), bazılarında ise direnişin 24 yıl sürdüğü (9. sınıf DK:32 ve 35) belirtilmektedir. 
Balkanları ele geçirmiştir. (6. sınıf DK: 118) Aynı şey, Osmanlı’nın Balkanlardaki yayılmasına daha çok yer verilen Arnavutların tarihi konulu dokuzuncu s1nıf (s. 27) ve on ikinci sınıf (s. 62-64) ders kitapları için de geçerlidir. Elbette her şeyin çok kısa ve basitleştirilmiş halde sunulması gerektiği ders kitaplarında Osmanlı'nın Balkanlardaki yayılmasının ve hatta nominal hakimiyet kurma sürecinin tüm boyutları ve özellikle iniş-çıkışları anlatılamaz, ancak en azından daha dikkatli bir dille bunun ima edilmesi ve öğrencilerin uyarılması (doğru tarihsel bilinç oluşturma adına) mümkündür. Bu anlatıda dikkat çeken, sürekli olarak Osmanlıların 'yabancı güçler' olarak dışarıdan gelmiş, hep yabancı kalmış ve yüzlerce yıl sonra tekrar geri püskürtülecek bir unsur olarak sunulmasıdır! Balkanları ve Arnavutluk'u istila eden ve yüzlerce yıl sonra tekrar geri püskürtülecek olan bu yabancı unsurların askeri üstünlüğü övülmekte (6. sınıf DK: 117; 12. sınıf DK: 62), sadece Arnavutluk tarihi konulu dokuzuncu ve on ikinci sınıf tarih ders kitaplarında o sırada merkezi güçlü bir yapının mevcut olmadığı Balkanlardaki kaotik durumdan (anarki) söz edilmektedir. (9. sınıf DK: 27; 12. sınıf DK: 63)

\section{i. Balkanlarda yayılma sürecinde dönüm noktası olarak Kosova Savaşı (1389)}

Osmanlı'nın Balkanlarda yayılma süreciyle ilgili anlatılarda öne çıkarılan olayların başında, bir dönüm noktası olarak görülen Kosova Savaşı (1389) gelmekte ve değişik sınıfların tarih ders kitaplarında bu savaşa ilgili bölümlerde muhakkak değinilmektedir. (6. sınıf DK: 118; 9. sınıf DK: 27; 12. sınıf DK: 62 ve 63) Ayrıca, on birinci sınıf ders kitabında metin içinde değinilmese de bölüm başındaki kronolojik tabloda verilmektedir. (s. 18) Bu anlatıda dikkati çeken şeyler şunlardır: Balkanlardaki Osmanlı yayılmasında ilk muharebe, Osmanlı/Türkiye tarihyazımında "Çirmen Muharebesi" olarak bilinen 1371 tarihli "Meriç Muharebesi" dir ve bu muharebe Balkan koalisyon ordularının Osmanlı'ya karşı yenilgisiyle sonuçlanmıştır. (6. sınıf DK: 118; 9. sınıf DK: 27) Anlaşılan Arnavut tarih ders kitaplarına göre bu yayılma, Osmanlıların bugünkü Türkiye sınırlarının daha batısına doğru ilerlemesiyle başlamakta; yani Balkanların doğu sınırını bugünkü Türkiye'nin batı sınırları oluşturmaktadır! Oysa bu yayılmanın başlangıcı olarak, 1352'de Çimpe Kalesi'nin Osmanlı'ya verilmesi ve özellikle 1354 yılında Gelibolu'nun ele geçirilmesi kabul edilmektedir. Nitekim 1361 yılında Edirne'nin ele geçirilmesinden sonraki on yıl boyunca Osmanlı bir Balkan ülkesine dönüşmeye başlamıştır. On ikinci sınıf ders kitabında da önce bu savaşlardan 
söz edildikten sonra 1371 Çirmen Muharebesi'nden (Meriç Muharebesi) ilk muhabere olarak değil "Meriç kıyısında belirleyici bir savaş" olarak söz edilmektedir.

1389 yılında Kosova Ovası'nda "veya (Priştine yakınlarındaki) Dardani Ovası'nda” (9. sınıf DK: 27) yapılan büyük muharebede ise Osmanlı'nın bu yayılma sürecini durdurmak için bir araya gelen "Sırp kralı Lazar liderliğindeki Balkan güçleri (6. sınıf DK:118)" içerisinde "Sırp ve Boşnakların yanı sıra Arnavut, Ulahlar gibi yarımadanın diğer halkları" da vardır. (12. sınıf DK: 63) Arnavutların tarihi ile ilgili dokuzuncu sınıf tarih ders kitabında, bu savaşa katılan 'Arnavut' beylerinden/prenslerinden üçünün adı geçer: Gjergj II. Balsha, Gjon Kastiroti ve Teodor Muzaka. (9. sınıf DK: 27) Yine Arnavutların tarihi ile ilgili on ikinci sınıf ders kitabında ise bunlardan sadece birincisi tekrarlanarak iki yeni isim (Andrea II Muzaka ve Dhmitër Jonima) eklenmekte ve bu savaşın bilinen en meşhur kahramanlarından birinin de 'Arnavut' savaşçı Teodor II Muzaka olduğu belirtilmektedir. (12. sınıf DK: 63) Bu kişilerin tamamen şahsi ve yerel çıkarları için savaşan ve etnik kimlikleri konusunda olduğu kadar aidiyetleri konusunda da bir şey söylemenin zor olduğunu unutumamak gerekir. Günümüzde kullanıldığı anlamıyla bu isimlere herhangi bir açıklama veya uyarı olmadan 'Arnavut' denilmesi, ezelden beri var olan bir Arnavut ulusu algısına sahip olabilecek okul öğrencileri için yanıltıcıdır. Aynı hataya, bu savaşta Osmanlı padişahını öldüren Millosh Kopili'nin (hakim Sırp anlatılarının tersine) Arnavut olduğu belirtilirken de düşülmektedir. (9. sınıf DK: 27) Sosyalist dönem sonrası Arnavutluk ders kitaplarında gözlemlenen, bir şekilde Kosova Savaşı'nda Arnavutların rolünü öne çıkarma eğiliminin nedeni, o sırada yaşanan Kosova sorunu olabilir. ${ }^{36}$

Aynı zamanda bölgeye giren yabancı bir unsur olan Osmanlı'ya karşı ilk direnişte Arnavutların da yer aldıkları belirtilerek, böylece genelde Balkanlı olmayan ve sonunda Balkanlardan atılan 'yabancı Osmanlı' imgesi de dolaylı olarak beslenmektedir.

\section{ii. Osmanlılaş(tır)ma sürecinin, yani Osmanlı'ya eklemlenme (entegrasyon) veya içerimlenme (incorporation) sürecinin ilk evresi}

Osmanlı'nın Balkanlara girişinden itibaren diğer Balkan yerel güçleri gibi Arnavut yerel güçleri de bu yayılmaya direnmiş, ancak bir yandan da birbirleriyle

36 Kostovicova, "The Portrayal of the Yoke: The Ottomans and Their Rule in the Post-1990 Albanian-Language History Textbooks", 272. 
rekabetleri ve hatta çatışmalarını sürdürmüşlerdir. Nitekim Osmanlı'nın bölgedeki ilk yayılma sürecinde bu çelişkilerden yararlanma taktiği çok önemli rol oynamıştır. 1389 yılında Kosova Savaşı'nda bölge temel güçlerinin yenilgisinden sonra bölgeye hakim olan Osmanlı’ya karşı direniş, bugünkü Arnavutluk topraklarında hüküm süren yerel güçler arasında da uzun süre devam etmiştir. Ancak bu direniş bugünkü Arnavutluk'un tamamı için geçerli olmamış; tam tersine bugünkü Arnavutluk'un güneyi ile Arnavutça konuşulan bugünkü Makedonya'nın batısı ve Yunanistan'ın kuzeybatısındaki yerel güçler Osmanlı'ya entegrasyon sürecine daha erken başlayarak, diğer bölgelerin Osmanlılaştırılması sürecine bazen Osmanlı askerleri olarak katılabilmişlerdir.

Arnavutluk tarihinin anlatıldığı dokuzuncu sınıf ders kitabında "Osmanlı’nın istilasının sonuçları ve XV. yüzyılın $20^{\prime}$ li ve 30 'lu yılları ayaklanmaları” altbölümünde üç önemli ekonomik ve siyasi sonuç sıralanmaktadır: 1) Tarım alanları zarar gördü ve şehirler yandı veya talan edildi; 2) Arnavutluk'ta hakim Arbër (Arnavut) beyler verimli topraklarını kaybettiler ve vasaller olarak işgalci padişaha hizmet etmek, "haraç (yıllık vergi)" ödemek ve gerektiğinde ordusunda yer almak zorunda kaldılar; ve 3) toprak Osmanlı devletinin malı ilan edildi ve "tüm köylülere yıllık vergi (haraç) yüklendi.” (9. sınıf DK: 28)

Dokuzuncu sınıf ders kitabında bu olumsuz koşulların isyanlara yol açtığı belirtilirken, böylece tüm dönemler için geçerli olan bir imge olarak Osmanlı boyunduruğuna karşı sürekli isyan eden Arnavutlar imgesinin inşasına daha ilk dönemden başlanmaktadır. Zaten Osmanlı’nın bölgede yayılmasına karşı direnişte önemli rol oynadığı belirtilen Arnavutlar (aslında yerel beyler), şimdi de daha başından Osmanlı boyunduruğuna karşı isyan eden, özgürlüklerine düşkün insanlar olarak sunulmaktadır. (9. sınıf DK: 28) Bunlardan özellikle öne çıkarılan iki isyandan biri Gjergj Arianiti'nin 1432 yılındaki isyanıdır ki sonuçta bunu bastıran Osmanlı ordusunun Shkumbin ırmağı kenarındaki bir muharebede yenilgiye uğratılması, "Arbërların [Arnavutların] güçlü Osmanlı birliklerine karşı aldığı ilk zafer" olarak sunulmaktadır. (9. sınıf DK: 28) Osmanlı’ya karşı dönemin ikinci önemli ayaklanması olarak anılan, 1428 yılında çıan Gjon Kastrioti önderliğindeki isyan ise isyanın bastırılmasının ardından vasal olarak kabul edilen Gjon Kastrioti'nin oğlu Arnavutluk ulusal tarihinin en önemli figürü olan İskender Bey’i Osmanlı sarayına rehin (peng) vermesi bağlamında çok önemlidir. (9. sınıf DK: 28) Nitekim bu bölümde Gjon Kastiroti'nin temsili resmi altında kendisi hakkında kısa bir bilgi verilmekte ve bu rehin meselesi de orada anlatılmaktadır 
(9. sınıf DK: 28) (Aşağıda göreceğimiz gibi, bu resim ve altında verilen Gjergj Arianiti'nin amblemi, on ikinci sinıf ders kitabında tekrar verilecektir. [s. 63])

On ikinci sınıfta da, bölgenin Osmanli’ya eklemlenme süreci veya Osmanlılaş(tırıl)ma süreci (böyle kavramsallaştırılmasa da) anlatılmaktadır: Osmanlı birçok Arnavut şehrini geçici olarak istila etmiş, bu sırada birçok yerel bey vasallık statüsünü kabul etmişti. Bunların birçoğu çocuklarını güvence olarak padişaha rehin vermiş ve bölgedeki istila harekatlarında Osmanlı ordusunda yer almak zorunda kalmıştır. Bu dönemde Osmanlı, Balkanlardaki ilk idari birimlerinden biri olan, Gjirokastro merkezli Arnavut Sancağı'nı (sancak-i Arvanid) kurmuştur. 1431-1432 yılında bu sancak için tutulan sayım defterine tüm nüfus, toprak ve vergi bilgilerinin kayıt edildiği belirtilirken; aynı dönemde benzer sayımların Korça, Permet ve Konica için de yapıldığı söylenerek, aslında Osmanlılaşma sürecinin en önemli adımının atılmış olduğu öğrencilere gösterilmektedir. (12. sınıf DK: 63-64)

Burada da yayılma sürecine tepki olarak ortaya çıkan Arnavut ayaklanmaları (Osmanlı tarihi boyunca süreceklerin ilk örnekleri olarak) anlatılmaktadır: $\mathrm{Bu}$ sefer isyan tarihi 1429-1430 olarak verilmekte ve isyanın Osmanlı orduları komutanı Evrenozlu İshak Bey tarafından bastırıldığı söylenmektedir. Daha sonra 1432-1435 yılları arasında birçok isyanın çıktığı ve bunlar arasında en önemlisinin Gjergj Arianiti önderliğinde gerçekleşen isyan olduğu ve Osmanlı ordularınca bastırılsa da bu ve diğer isyanların "yerel halk arasında özgürlük ruhunu canlı tutmaya yardımcı oldukları" ifade edilmektedir. (12. sınıf DK: 64) Oysa, tam da sayım ve kayıt sonrası gerçekleşen bu ayaklanmalar gibi sonraki birçok ayaklanmanın, merkezi hükümetin taleplerine karşı (çıkarları zedelenen yerel beylerin önderliğinde) tepkiden ibaret olduğu, ulusallıkla veya halkın özgürlüğü ile ilişkisi olmadığı açıktır. Üstelik bu ayaklanmalar genelde birbirinden bağımsız olduğu gibi beyler ve (Arnavutça konuşan) farklı bölge halkları arasında çelişkiler ve çatışmalar olduğu, bu nedenle tarafların sıklıkla birbirlerine karşı Osmanlı ile işbirliğini tercih ettiği de bilinmektedir.

Bu arada, altıncı sınıf ders kitabında Bizans' ın başkenti Konstantinopolis' in "düşmesi” (6. sınıf DK: 118) ve Fatih tarafından şehre İstanbul adının verilmesine (s. 118) değinilirken, "bunun Avrupa için olumsuz sonuçları olduğu, çünkü Avrupa ticaret yollarından birinin kapandığı söylenmektedir. (s. 118)

Ayrıca, Arnavutluk'u ele geçiren Osmanlı'nın, Balkanları/Arnavutluk'u Avrupa Rönesans'ından kopardığı dile getirilmektedir. 
Osmanlı'nın Balkanlarda yayılması sürecinin sonucu olarak Arnavutluk'ta Osmanlı hakimiyetin kurulması (Osmanlılaştırma) süreci anlatılırken öne çıkarılan kavram/olgular şunlardır: Balkanlarda altyapı yapımı (olumlayan bir dille) not edilirken, yeni camiler yaptıkları da belirtilmekte, böylece adı verilmeden ve hakkıyla ele alınmadan İslâmlaş(tır)ma süreci ima edilmekte, ancak bu Osmanlılaşma sürecinin kaçınılmaz bir parçası olarak gösterilmektedir.

İlk zamanlar, Osmanlı iktisadi ve idari yapısını kabullenen değişik dinlerden elit gruplar kendi dinlerini ve elit konumlarını korumuşlardır. Bunun yanında genel kabul gören Osmanlı yönetiminin dinsel 'hoşgörü' politikasıyla, farklı dinlere mensup sıradan halk da ikinci sınıf da olsa Osmanlı tebaası olarak var olmuştur. Aynı şeyin Arnavutluk'ta Osmanlı hakimiyetinin ilk yüzyılında özellikle hakim olduğu bilinmektedir. Ders kitaplarında bunun üzerinde pek durulmazken, birkaç kez Arnavutluk'ta üç dinin varlığını sürdürdüğü söylenmekte ve sadece bir kez de Osmanlıların diğer dinlere karşı hoşgörülü olduğu belirtilmektedir.

\section{iii. İskender Bey ve 'ulusal' (!) direniş}

Osmanlı’nın Balkanlarda yayılma dönemi anlatılarında öne çıkan bir başka olgu da modern Arnavut ulusunun söylemsel inşasında anahtar rol oynayan İskender Bey figürüdür. ${ }^{37}$

Aslında modern öncesi döneme ait literatürde, Avrupa'da İslâm'ın yayılmasına karşı direnişin Hıristiyan kahramanı olarak sunulan ve hatta etnik kimliği tartışmalı olan İskender Bey'in 'ulusal kahraman' ilan edilmesi, on dokuzuncu yüzyılda Arnavut ulusunun söylemsel inşa süreciyle başlamıştır. Tamamen Batılı kaynaklardan beslenilerek yaratılan ve o zamandan beri sürekli yeniden-üretilen bu modern mitos, ${ }^{38}$ ders kitaplarında özel bir yer tutmaktadır. Ders kitaplarındaki Osmanlı algısının inşasında da bu bölümler (İskender Bey'in işgalci Osmanlılara/Türklere karşı direniş öyküsü) anahtar roldedir.

Dünya tarihinin bir parçası olarak, altıncı sınıfta okutulan tarih kitabında ilk defa öğrencilerin karşısına çıkan bu anlatıya göre, Osmanlı’nın Balkanlara

37 Oliver Jens Schmitt, „Skanderbeg“. Der neue Alexander auf dem Balkan (Regensburg: Verlag Friedrich Pustet, 2009); Bilmez, "Skanderbeg in the Turkish Historiography: An attempt towards a critical assessment".

38 Egin Ceka, "Ndërgjegje historike. Muzeu Kombëtar dhe Muzeu i Skënderbeut si institucione të religjionit civil shqiptar të komunizmit", Përpjekja 21 (2005): 121-47. 
girişinden itibaren Arnavut yerel güçleri bu yayılmaya direnmiştir. En uzun süreli direnişin lideri İskender Bey'in tüm Arnavutları temsilen (ve adeta tüm Arnavutları birleştirip arkasına alarak) başlattığı direniş ise tamamen kronik bir kavramsallaştırma ile adeta ulusçu bir hareket olarak sunulmaktadır.

Arnavut ulusunun inşa sürecinde anahtar rol oynayan İskender Bey imgesiyle ve tarihiyle ilgili bu yanlışların tamamı, en yüksek seviyede Arnavut tarihçiler ve kurumları tarafından üretilip yaygınlaştırılmaktadır. Üstelik bugün daha da önemli ve güçlü şekilde devam eden bu üretim sonucunda, Arnavut ulusunun söylemsel inşasında kullanılan imgeler (mitler) arasında en kalıcı imge olmuş ve yüzyıldan fazla bir zaman içerisinde değişen farklı rejimlerde değişmeyen tek ana imge olarak kalmış ve herhangi bir dönemde farklı grupların ortaklaştığı temel anlatı olma niteliğini de korumuştur. Tiran'ın merkezinde devasa bir heykelden başlamak üzere Arnavutluk'ta günlük yaşamda her an medyadan edebiyat ve sanata kadar her yerde insanların karşısına çıkan bu imge ile Arnavutlar, aslında hayatlarında ilk kez sistemli bir şekilde okulda karşılaşmaktadırlar. Osmanlı/Türk imgesinin inşasında da hayati rol oynayan bu imgeyle ilgili bu dramatik ve hat safhada romantize edilmiş anlatıyı şu şekilde özetlemek mümkün: Yukarıda sözü edilen ayaklanmalar bastırılmış ve kahraman Arnavut direnişçilerden, "büyük stratejik, askeri ve ekonomik öneme sahip" (9. sınıf DK:29) Kruja ve çevresinde hüküm süren Gjon Kastiroti, daha 1409 yılında Osmanlı vasallığını kabul ederek güvence olarak büyük oğlu Stanish'i Osmanlı sarayına rehin göndermiş ve 1415 yılında Kruja’nın da Osmanlı'nın eline geçmesinden sonra küçük oğlu Gjergj'i

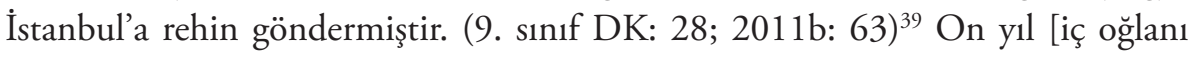
olarak] kaldığ İstanbul'da eğitim gören ve çok başarılı olarak bizzat padişah tarafından İskender (Skender) adı verilen Gjergj Kastrioti, Osmanlıcayı ve Doğu dillerini öğrenmiş, aynı zamanda da Müslüman olmuş ve kendisine "bey" unvanı verilmiştir. (9. sınıf DK: 30; 2011b: 65) ${ }^{40}$ Memleketinden küçük yaşta ayrılmasına rağmen, bilinçaltında, atalarının dinine, geleneğine ve topraklarına olan aşkını canlı tutmuştur. Osmanlı'ya karşı kurtuluş savaşı vermek için uygun zamanı bekliyordur. (12. sınıf DK: 65) Bu 'uygun zaman', İskender Bey'in de Osmanlı saflarında katıldığı 1443 yılındaki Niş Muharebesi’nde Osmanlı ordusunun Janosh Hunyadi komutasındaki Macar ordusuna yenilmesiyle gelmiştir: Birliğiyle

39 İki ayrı ders kitabında da kullanılan (İskender Bey'in babası) Gjon Kastrioti'ye ait aynı resmin altında verilen bu bilgiler için bkz. 9. sınıf DK: 28; 12. sınıf DK: 63.

40 İskender Bey’e (Skenderbeu veya Ggergj Kastrioti’ye) ait aynı resim, iki ayrı ders kitabında da kullanılmakta ve resim altlarında aynı bilgi verilmektedir. (9. sınıf DK: 30 ve 12. sınıf DK: 65) 
birlikte cepheden ayrılarak [askerden kaçarak] Kruja’ya gider ve 28 Kasım 1443 tarihinde [bazılarına göre Sultan'dan alındığı iddia edilen sahte veya tahrif edilmiş bir mektup sayesinde] şehrin denetimini ele geçirir. (9. sınıf DK: 30; 2011b: 65) "Kruja’nın kurtuluşundan sonra ..." (9. sınıf DK: 30) kısa zaman içinde denetimi altındaki toprakları genişleten (9. sınıf DK: 30; 2011b: 65) İskender Bey'in bu yayılma mücadelesinde asıl rakiplerinin Osmanlı Devleti değil (Brankoviç ve Srnojeviç gibi) diğer yerel beyler olduğu ders kitaplarında anlatılmamakta; tek düşman olarak işgalci ve dış (yabancı) unsur olan Osmanlı gösterilmektedir.

İslâmiyet'i reddederek bölgenin diğer beyleriyle Osmanlı’ya karşı bir ittifak kurmaya çalışan İskender Bey'in bu amaçla 1444 yılında Lezha'da toplanılmasına ön ayak olduğu ve liderliğini yaptığı toplantı (Kuvendi i Lezhës), tarih ders kitaplarında adeta tarihte 'ilk Arnavut ulusal kongresi/toplantısı/meclisi' muamelesi görürken (9. sınıf DK: 31; 2011b: 66) ${ }^{41}$ buradan çıkan ittifak anlaşması da (Lidhja e Lezhës = Lezha Birliği), bir tür 'ulusal birlik anlaşması' olarak anlatılmaktadır. (9. sınıf DK: 30-31; 2011b: 65-66)

Gerek bu anlaşmanın koşulları gerekse İskender Bey’in bölgede kurduğu yönetim, adeta bir Arnavut devleti olarak sunulmakta ve ulusal ordu gibi tasvir edilen güçlü ordusu ile adeta bir ulus devlet gibi sunulan ve uluslararası ilişkiler kuran yönetim övgüyle anlatılmaktadır. "Anavatan, özgürlük ve birlik" sembolü (9. sınıf DK: 35; 2011b: 70) ve "Arnavut kahramanı" (12. sınıf DK: 70) olan İskender Bey'in yüceltildiği bu anlatıya, dokuzuncu ve on ikinci sınıfta istisnai olarak iki ayrı bölüm ayrılmakta ve ikinci bölümde İskender Bey'in işgalci zalim Osmanlı ordularına karşı kahramanca savaşları anlatılmaktadır. 1468 yılında vefat eden İskender Bey'le ilgili sunulan çok sayıda görsel malzemenin hemen hepsi (değişik resimleri, tacı, amblemi ve bugün Tiran'ın ana meydanındaki heykeli) altıncı, dokuzuncu ve on ikinci sınıf ders kitabında tekrarlanmıştır. İskender Bey'in en önemli düşmanı Fatih Sultan Mehmet'in resmine de altıncı (s. 126) ve dokuzuncu sınıf (s. 32) ders kitaplarında yer verilirken; on ikinci sınıf ders kitabında, Arnavut Marin Barleti'nin Latince yazdığı İskender Bey'in hayatını anlatan kitabının kapağı da verilmiştir. (s. 70; ayrıca bkz. 6. sınıf DK: 133)

Aslında kendi döneminde ve sonraki dönemlerde Avrupa’da daha çok Osmanlı’nın Hıristiyan Avrupa aleyhine topraklarını genişletmesi sürecini

41 Dokuzuncu sınıf ders kitabında "XIV. yüzyılın ilk ulusal meclisi" denirken (9. sınıf DK:31); on ikinci sınıf ders kitabında "bugüne kadar bilinen ilk Arnavut forumu" olarak nitelenmektedir. (12. sinif DK:66) 
durdurmayı başarmış bir Hıristiyan kahraman olarak meşhur olan İskender Bey’ in bu unvanına kısaca değinilmektedir. (9. sınıf DK: 35)

\section{b) Klasik Osmanlı (XVI-XVII. yüzyıllar): Sosyo-ekonomik ve kültürel yapı}

1468 yılında İskender Bey’in Lezha'da ölümünden kısa süre sonra, (1466 ve 1467 yıllarındaki büyük kuşatmalara da direnen) Kruja şehrinin 1478 yllında İskender Bey'in devamı olan kuvvetlerden alınması ve 1479 yılında İşkodra'nın Venediklilerden alınmasından sonra bugünkü Arnavutluk'un kuzeyini de ele geçirmiş olan Osmanlı, 1506 yılında Dıraç (Durrës) şehrini de aldıktan sonra bugünkü Arnavutluk topraklarının tamamında hakimiyetini kurmuştur. Ancak bu dönem (1481-1506) için de dokuzuncu sınıf ders kitabında öne çıarılan şey, Arbër beylerinin devam eden isyanlarıdır. (9. sınıf DK: 35-36)

Bundan sonraki üç yüzyılı (XV., XVI. ve XVII. yüzyıllar) bölgede Klasik Osmanlı yönetimi olarak tanımlayacak olursak, klasik Osmanlı idari, kültürel, siyasi, askeri ve sosyal kurumlarının tamamen yerleştiği bu dönemde, daha önce (XV. yüzyılda) Osmanlılaş(tırıl)ma sürecinin tamamlandığını ve artık buna İslâmlaş(tırıl)ma sürecinin de eklendiğini belirtmek gerekir.

Genelde Türkiye tarihyazımında da görece az ilgi gören bu döneme, Arnavutluk ders kitaplarında da az yer ayrılmaktadır. (7. sınıf DK: 89-90; 9. sınıf DK: 37-43; 11. sinıf DK:18-21; 12. sinıf DK: 71-76)

Bu dönem ilk olarak altıncı sınıfta kısaca anlatılırken, XIV. yüzyılda kurulan Osmanlı İmparatorluğu’nun doruk noktasına XVI. yüzyılda ulaştığı ve XVII. yüzyılda inişe geçtiği belirtilirken, bağımsızlığını ilan eden Balkan devletlerinin kopmasıyla toprak kaybı yaşanan (aslında modernleşme/gelişme/ilerleme yüzyılı olarak da görülebilecek) XIX. yüzyıl da buna katılmaktadır. (7. sınıf DK: 89) Türkiyede de uzun süre hakim olan 'gerileme paridagması'na uygun bu dönemlendirmeye göre, bu düşüş/gerileme, 1683 yılında Osmanlı'nın Viyana kuşatmasından başarııı dönmesiyle başlamaktadır. Bu dönemin belirleyici özelliği, Osmanlı'yı giderek zayıflatan Osmanlı sarayındaki güç savaşımı, entrikalar ve komplolar olmuştur ve bunların dolaysız sonucu, sürekli toprak kaybı olmuştur. (7. sinıf DK: 89) On birinci sınıf ders kitabında da bu dönemin iki ayrı alt-döneme ayrılabileceği söylenmekte ve buna göre anlatılmaktadır: XIV.-XVII. yüzyıllar arasındaki yükseliş, güç ve parlaklık dönemi ve XVII.-XX. yüzyıllar arası (çözülme/yıkılmayla bitecek olan) düşüş/gerileme dönemi. (11. sınıf DK: 18) 
Genelde Osmanlı'nın klasik yapısına gelince, padişahın hakimiyetinin dayandığı dört gruptan bahsedilmektedir: Saray, bürokrasi (kalemiye), Müslüman din adamları ve ordu. (11. sınıf DK: 18-19). Balkanlarda bu dönemi anlatmak için ele alınan kurumlar ve olgular şunlardır: İdari birimler olarak eyalet (elayet), sancak (sanxhaqe), kaza ve nahiye (nahije) sistemi (9. sınıf DK: 37); has, zeamet ve tımar (hase, zijamete ve tımare) sistemi, sipahilik, reaya, haraç, (XVII. yüzyılda doğan ve zamanla yerel beyleri ve ademi-merkeziyetçi paşalıkları ortaya çıkaracak olan) çiftlik gibi önemli kavramlar açılanmaktadır (9. sınıf DK: 37) ve 3) Osmanlı'nın hakimiyeti sonrası gelişen şehirler, Arnavutluk'ta önemli rol oynayan Katolik rahiplerin açtığı ve Arnavutça da eğitim veren din okullarının açılması ile bunun sonucu olarak (Meshari (1555) eserini yazan Pjetër Budi, Frang Bardhi ve Pjetër Bogdani'nin adı verilerek) Arnavut edebiyatının "temellerinin atılması"na değinilmekte; resim ve mimaride gelişme (cami, kilise, hamam, çeşme, saat kulelerinin şehirlerin çehresini değiştirdiği belirtilmekte) anlatılmakta ve nüfusun dinsel yapısında yaşanan önemli değişikliğin (Katolik ve Ortodoks Hıristiyanlık'a, özellikle XVIII. yüzyılda yayılan İslâm’ın eklenmesinin) altı çizilmektedir. (9. sinıf DK: 38)

Arnavutluk'ta dinsel yapının değişimi konusunda, asıl kitlesel İslâmlaşmanın yaşandığı XVII. yüzyıla, doğru bir şekilde vurgu yapılırken (9. sınıf DK: 38), genelde İslâm'ın Arnavutluk'a giriş ve yayılma süreci ile bunun dinamikleri (ekonomik, sosyal, vd.) hiçbir yerde anlatılmamaktadır.

Arnavutluk'un inanç gruplarından bahsedilen her yerde sadece üç grubun mevcut olduğu belirtilirken (9. sınıf $\mathrm{DK}$ : 38); bugün ülkenin üçüncü büyük inanç grubu olduğu resmen kabul edilen Bektaşilerden ve Bektaşilikten hiçbir yerde söz edilmemektedir. ${ }^{42}$ Oysa başından beri bölgenin Osmanlılaşması ve Müslümanlaşması sürecinde hayati rol oynayan Bektaşiliğin bu süreçteki rolünün ve bu inancın kendisinin Arnavutluk'a giriş ve gelişme sürecinin tarih ders kitaplarında yer almaması büyük eksikliktir.

Genelde klasik Osmanlı dönemi anlatısında olumlu bir dil kullanılırken, bu dönemde yaşanan Arnavut isyanlarına da özel bir bölüm ayrılmakta ve bunun nedenleri pek açılanmamaktadır. (9. sınıf DK: 39-41) Ayrıca, klasik dönemin klasik yerel feodal/köylü ayaklanmalarından olan bu isyanlar, Arnavutların Osmanlı'ya karşı ayaklanması olarak sunularak önemli bir hata

42 Bülent Bilmez, “Tarihyazımında Kaynak Olarak Seyahatname: Evliya Çelebi'de Arnavut Bektaşileri”, Toplumsal Tarih 97 (2002): 32-42. 
yapılırken, öğrencilere yanlış Osmanlı imgesi aktarılmaktadır: Osmanlı halkının bir kesiminin Osmanlı Devleti'ne veya yerel yöneticilerine karşı ayaklanması "Osmanlılara karşı Arnavut ayaklanması" olarak sunulunca, Osmanlıların aslında kim olduğunun anlaşılmadığı ortaya çıkmaktadır, çünkü hem Osmanlı Devleti'nin yöneticisi hem de halkı anlamında Osmanlılık, diğer tüm halklar gibi Arnavutları da kapsamaktaydı. Yani sadece, ayaklananın Arnavutlar olduğu söylenerek anakronik bir ifade kullanılmış olmuyor, aynı zamanda Arnavutları kapsamayan bir Osmanlılık tanımı mümkünmüş gibi yanlış bir anlayış sergileniyor.

Klasik dönemin sonunda, XVIII. yüzyılın sonunda ortaya çıkan güçlü ayan ve bunlar arasında öne çıkan ve etkisini XIX. yüzyılın başına kadar artırarak sürdüren Paşalıklar (Kuzeyde Buşatı Hanedanı/ailesi ve Güneyde Tepedelenli Ali Paşa'nın özerk veya yarı-bağımsız yönetimleri) da adeta Osmanlı'ya sürekli Arnavut direnişinin bir aşaması olarak anlatılmaktadır. (9. sınıf DK: 41-43; 2011 b: 74-76)

\section{c) Modernleşme sürecinde Osmanlı ve ayaklanma/aydınlanma/ uluslaşma sürecinde Arnavutlar (1830-1912)}

Arnavutluk'ta tarih kitaplarında nicelik ve nitelik olarak en büyük yeri Osmanlı modernleşme süreci (Tanzimat ve merkezileşmeye karşı 'Arnavut' ayaklanmaları) ve özellikle bu dönemdeki Arnavut 'yeniden uyanışı' (Rilindja) ve 'ulusal hareket' (Lëvizja Kombëtare) almaktadır.

Bu dönemle ilgili dikkati çeken bir çelişki, daha on dokuzuncu yüzyılın başında ulusun söylemsel inşa sürecinde ortaya çımış ve günümüze kadar devam etmiştir: Kendisi modernist olan aydınlar veya modernist anlatılar, Osmanlı modernleşme sürecini (özellikle merkeziyetçilik bağlamında) olumsuz bir gelişme olarak sunarken, buna karşı her türlü yerel tepkiyi olumlamakta ve bunları bir yandan ezelden beri var olan Arnavut direnişinin devamı, diğer yandan modern/ ulusçu mücadelenin başlangıcı olarak sunmaktadır.

Aynı şekilde ders kitaplarında Osmanlı modernleşme sürecinin başlangıcı sayılan Tanzimat' in anlatılması (7. sınıf DK: 91-92; 9. sınıf DK: 44-46; 2011b: 77) ile başlayan bu tavır, özellikle Arnavut 'Rönesans'ı / 'Yeniden Uyanışı'nın (1830’lar-1878) tartışıldığı bölümlerde açıç̧a sergilenmektedir. (7. sınıf DK: 102-103; 9. sinıf DK: 46-68; 2011b: 78-86) 
Bu arada, XIX. yüzyıl boyunca devam eden Balkanlardaki bağımsızlıkçı ulusçu hareketlere, yani Osmanlı'nın boyunduruğundan kurtuluş savaşı veren Balkan halklarına özel ilgi gösterilmektedir. (7. sınıf DK: 93-95 [Yunan örneği]; 96-97 [Sırp örneği]; 98-99 ve 100-101 [Romanya örneği])

Bunun bir parçası olarak görülen (aslında halkın çoğunluğunun Müslüman olması nedeniyle aynı zamanda bir ilk olan) Arnavut ulusçu hareketi (1878-1908) ise beklenildiği üzere, ders kitaplarında en çok önem verilen konu olmaktadır. (9. sınıf DK: 46-68; 11. sınıf DK: 78-79; 12. sınıf DK: 77-86) Bu hareketin başlangıcı olarak sunulan Prizren Birliği (1878-1881/85) ise bu anlatının en önemli parçasıdır. (9. sınıf DK: 50-54; 11. sınıf DK: 79; 12. sınıf DK: 78-79)

Bir bütün olarak Abdülhamid rejimi üzerinde durulmazken, bu dönemde (1881/85-1908) güçlenen Arnavut kültürel milliyetçiliği (ulusun söylemsel inşasına hizmet eden dil, edebiyat, coğrafya ve tarih çalışmaları) özellikle ele alınmakta (9. sınıf DK: 57-58; 2011b: 80-82) ve bu gelişmeye adeta ters düşen (bir sapma olarak görülebilecek) İpek Birliğinnin (1899) mücadelesine (bu çelişki sorunsallaştırılmadan) değinilmektedir. (9. sınıf DK: 59; 2011b: 79) Bu dönemde Abdülhamid rejimine muhalif olarak ortaya çıkan Jön Türkler'den ise adeta bir Türk hareketi olarak söz edilmekte, bu kuşağın (ve kurduğu İttihat ve Terakki Cemiyeti'nin) kurucuları ve önemli üyeleri arasında Arnavutların da bulunduğu ve Avrupa dillerinden aktarılan bu isimle anılan bu hareketin (en azından 1908 öncesi dönemde) aslında Türk(çü)lükle ilgisi olmadığı belirtilmeyerek daha önce de Osmanlı ve Türk kavramlarının kullanımındaki kafa karışıklığı sergilenmeye devam edilmektedir. (9. sınıf DK: 62-63)

Bir 'Osmanlı Devrimi' olan 1908 Devrimi üzerinde pek durulmazken, bu devrimden sonraki süreç (1908-1912) adeta 'bağımsızlığa giden bir süreç' (önceki bölümlerdeki teleolojik anlayışa uygun olarak) olarak anlatılmaktadır. Burada dikkati çeken ilginç noktalardan biri de şudur: Dönemin Türk aydınları arasında ve sonradan Türkiye tarihyazımında hakim olan 'Arnavutların bağımsızlık ilan etmekle Müslüman kardeşlerine veya davaya ihanet ettikleri' söyleminin tersine; Arnavut aydınlara göre, İttihat ve Terakki yönetimindeki Türk aydınları devrimin kardeşlik, eşitlik ve adalet şiarlarına ihanet ederek Türkçülük politikaları izlemişler ve özellikle Müslüman Arnavutların ulusal uyanışını engellemek için ellerinden geleni yapmışlardır. Bu konuda verilen somut bilgi, Arnavutça eğitimin ve yayınların engellenmesi ve merkeziyetçi politikalar güdülerek yerel duyarlıkların gözetilmemesidir. 
Tam da bu hayal kırıklığının sonucunda kulüpler ve derneklerde örgütlenen ve süreli yayınlar ile kongre ve konferanslar aracılığıyla mücadele eden aydın Arnavut muhalefeti (1908-1912) (9. sinıf DK: 62; 2011b: 82) ise giderek radikalleşmiştir. Eğilimi, özerklikten bağımsızlığa kaymıştır ve Arnavutluk'taki yerel güçlerin merkeziyetçiliğe tepkisini (her yıl ortaya çıkan yerel ayaklanmaları) ulusçu taleplerle giderek daha çok birleştirmeyi başarmıştır. (9. sınıf DK: 63)

Nihayet 1912 yılında patlak veren ve sonuçta Osmanlı yönetiminin geniş bir özerlik anlaşmasını onaylamasıyla yatıştıılan Büyük Ayaklanma’nın ülke çapında yayılmasının ve örgütsel ve ideolojik olarak daha sistemli olmasının en büyük nedeni, bu muhalif aydınların yerli muhalif elitle işbirliğidir. (9. sınıf DK: 64-66)

Ancak (teleolojik bir yaklaşımla) tüm bu aydınlanma/yeniden uyanış sürecinin ve mücadelesinin adeta doruk noktası olarak sunulan 28 Kasım 1912'de Arnavutluk'un bağımsızlı̆̆ının ilan edilme süreci anlatılırken (9. sınıf DK: 6668), bunun bu sırada yapılabilmesinin asıl nedeni belirtilmemektedir: Sadece on ikinci sınıf tarih ders kitabında yer verilen Balkan Savaşı'nda (s. 84) Osmanlı'nın hezimete uğramış olması ve daha ilk ayından itibaren bu topraklardaki hakimiyetini fiilen zaten kaybetmiş olması.

\section{Bağımsızlık ve Osmanlı sonrası: Siyasi kopuş, kültürel kopuş çabası ve Türkiye Cumhuriyeti'nin 'dışarıdan' takibi}

Arnavutluk tarih kitaplarında genelde Osmanlı sonrası ilk dönemle (19131918/22) ilgili hiçbir bilgiye yer verilmemektedir. Yukarıda belirtildiği gibi, Arnavutluk'un Osmanlıdan fiilen kopması ve 1912 yılında bağımsızlığını ilan etmesi ve ertesi yıl sınırları Büyük Güçler tarafından da kabul edilerek resmen kopması sırasındaki Balkan Savaşları (1912-13) işlenmemektedir. Düne kadar anavatan olan ülke şimdi adeta yok olmuştur ve konu sadece Arnavutluk bağlamında ele alınmaktadır. Aynı anlayış, sekizinci sınıf (s. 13-21), dokuzuncu sınıf (s. 76-80), on birinci sinıf (s. 91-93) ve on ikinci sinıf (s. 87-92) ders kitaplarında yer verilen Birinci Dünya Savaşı anlatıları için de geçerlidir. ${ }^{43}$ Oysa bir Arnavutluk devletinin 'kurulması' daha on yıl alacağı gibi, Osmanlı'dan kültürel, sosyal ve iktisadi kopuş tüm çabalara rağmen uzun süre gerçekleşmeyecektir.

Diğer yandan, öğretim süresince Türkiye Cumhuriyeti tarihi sadece bir kez sekizinci sınıf tarih ders kitabında işlenmekte ve 1923-1938 arası dönemin

43 Bilmez, "Arnavutluk Ders kitaplarında Birinci Dünya Savaşı”. 
anlatıldığı bir bölümde, oldukça ilerlemeci/modernist dille Mustafa Kemal Atatürk ve devrimleri övülmektedir. (8. sınıf DK: 58-59) İlk olarak burada, geçmişin sembolü olan fes, türban, ferace ve çok-eşlilik gösterilmekte (8. sınıf DK: 59) ve Türkiye Cumhuriyeti'nde tüm bunların değiştiği ve bu arada din ve devlet işlerinin birbirinden ayrıldığı ve kadınlara seçme hakkı verildiği (1934) aynı resimde gösterilmektedir. (8. sınıf DK: 59) Burada tuhaf bir hata yapılarak Arapça yerine Türkçe'nin kabul edildiği iki kez belirtilmekte (s. 58 ve 59), Latin harflerinin kabulüne değinildikten sonra, bu reformların gerçek bir laik ve modern devlet yarattığı söylenmektedir. (s. 59)

\section{Sonuç}

Yukarıda ele aldığım örneklerde görüleceği üzere, Arnavutluk ders kitaplarında Osmanlı/Türk imgesi farklı olumsuz kategoriler altında ele alınmaktadır. Bütün bu ders kitaplarındaki Osmanlı/Türk imgesinin en olumsuz yorumu yüzyıllarca Arnavutları boyunduruk altında yaşatan ve sömüren 'işgalci/yabancı' bir unsur olarak Osmanlı/Türk anlatısıdır. Ulus devlet inşa süreci ve sonrasındaki deneyimler içerisinde kullanılan bu 'sömürü' vurgusu üzerinden uzun yıllar 'sömürülmüş' bir halkın bağımsızlığı anlatılmaktadır. Elbette bu anlatıda, yukarıda bahsettiğim gibi Osmanlı'nın aslında kimlerden oluştuğu ya da ne olduğuna ilişkin bir tarihselleştirme amacı güdülmemektedir.

Bu kategorilerden bir diğeri ise eskiyi temsil eden 'gerici' Osmanlı/Türk imgesidir. Arnavutluk'un aslında gerçekleştirebileceği 'milli rönesansını' ama bu işgal nedeniyle ertelemek durumunda kaldığının vurgulandığı bu anlatıda, 'geçmişi reddetme' algısı üzerinden her zaman var olmuş yeknesak bir Arnavutluk ülkesi ideali tahayyül edilmekte; aslında gelecek için tasarlanmaktadır. Oysa Osmanlı'nın bölgeye girişi ve yayılması sırasında böyle bir birim olmadığı gibi, bu topraklar ancak Osmanlı yönetimi altında bir araya gelmiş; sonrada tam bir bütünlüğe sahip olmamışlardır. Aynı merkeze bağlı olmak dışında fazla anlam taşımayan klasik Osmanlı yönetimi altında da bu durum devam ederken, bu dönemin sonunda ortaya çıan ademi-merkeziyetçi paşalıklar ise bölgesel/yerel nitelikli ve ulusallıktan tamamen uzak birimler olmuşlardır.

Bu statik algı, genelde yapılageldiği gibi, Osmanlı değerlendirmelerinde başından itibaren aynı Osmanlı söz konusuymuş gibi davranılması bağlamında da karşımıza çıkmakta ve 600 yıl boyunca Balkanları/Arnavutluk'u işgal etmiş (11. 
sınıf DK: 20) bu Osmanlı algısı günlük yaşamda her zaman karşımıza çıkan sağlam bir imge haline gelmiştir.

Bütün bu anlatılar içerisinde, Osmanlı/Türk imgesi ile ilgili olarak bu çalışmanın ortaya çıkardığı diğer kategorileri ise şöyle başlıklandırabiliriz: Çağdaşlaşma önünde engel olan İslâm dininin temsilcisi olarak Osmanlı/Türk; yabanc1/ dışarıya ait Osmanlı/Türk ve son olarak yaşanan bütün olumsuzlukların kaynağı olarak Şark, Osmanlı, Müslüman ve Türk özdeşliği gibi...

$\mathrm{Bu}$ sorunlu imgelerin her birini nasıl ve neresinden düzeltmeye başlamak gerekir karar vermek zor. Ancak bizzat ulus devletler tarafindan sürekli yeniden-üretilen ve yayılan bu tür sorunlu imgeler, o ulus devletlerin bekası için gerekli görülen 'ulus' algısının sürekliliği için elzem bulunmaktadır... Son yıllarda Balkanlarda özellikle ders kitaplarında imgebilim (imagology) konusunda yapılan çalışmalar ve sorunlu imgelerin (farklı topluluklarla ilgili imajların) düzeltilmesi için gerçekleştirilen bölgesel diyalog ve işbirliği girişimleri umut vericidir.

\section{Arnavutluk Tarih Ders Kitaplarında Osmanlı/Türk İmgesi}

Öz — Bu makalede, Osmanlı'dan ilk ayrılan Müslüman halk olan Arnavutlar tarafindan kurulan (1912) ve bugün halen nüfusunun büyük kısmı Müslüman olan Arnavutluk'ta okutulan tarih ders kitaplarındaki Osmanlı/Türk imgesi incelenmektedir. Bunun için önce konunun geniş bağlamını oluşturan, genelde modern Arnavut tarihyazımı ve tarih söylemlerini üreten kurumlar kısaca anlatılmakta, sonra konunun daha dar bağlamını oluşturan ders kitaplarının yazım ve kullanım süreçleriyle kurumsal çerçevesi ele alınmaktadır. Makalenin ana gövdesi ise şu anda okutulmakta olan tarih ders kitaplarının detaylı analizini içermekte ve bu bölümde belli başlıklar altında Osmanlı imgesini en bariz şekilde gösteren bazı temalara odaklanılmaktadır: a) Arnavutluk'ta Osmanlılaşma ve Müslümanlaşma süreci ve bu bağlamda Kosova Savaşı (1389); b) sürecin ilk evresi (XIV-XV. yüzyıllar) ve İskender Bey direnişi; c) Klasik Osmanlı döneminde (XVI-XVII. yüzyıllar) sosyo-ekonomik ve kültürel yapı; d) Osmanlı modernleşme sürecinde Arnavutluk ve Arnavutlar (1830'lar-1912); ve e) bağımsızlığın ilanı (1912) ve sonrası.

Anahtar kelimeler: Arnavutluk, Tarih ders kitapları, Osmanlı/ Türk imgesi, İmgebilim 


\section{Kaynaklar}

Adanır, Fikret: "Wandlungen des deutschen Türkeibildes in der ersten Hälfte des 20. Jahrhunderts". Zeitschrift für Türkeistudien 4, sayı 2 (1991): 195-211.

Adhami, Stilian: Muzeologjia Shqiptare. Tiranë: Gervis, 2001.

Aksoy, Nazan: Rönesans İngiltere’sinde Türkler. İstanbul: İstanbul Bilgi Üniversitesi Yayınları, 2004.

Alibațić, Ahmet: "Images of the Ottomans in History Textbooks in Bosnia and Herzegovina". İslâm Araştırmaları Dergisi 17 (2007): 103-37.

Alkan, Necmettin: Avrupa Karikatürlerinde II. Abdülhamit ve Osmanlı İmajı. İstanbul: Selis Kitapları, 2006.

Aslıtürk, Baki: Osmanlı Seyyahlarının Gözüyle Avrupa. İstanbul: Kaknüs Yayınları, 2000.

Barbarosoğlu, N.: ed. Tarih Öğretiminde Çoğulcu ve Hoşgörülü Bir Yaklaşıma Doğru. İstanbul: Türkiye Ekonomik ve Toplumsal Tarih Vakfı, 2003.

Barthold, Vasili Vladimiroviç: Rusya ve Avrupa'da Oryantalizm. Çeviren Kaya Bayraktar ve Ayşe Meral. İstanbul: Küre Yayınları, 2004.

Beller, Manfred: "Perception, Image, Imagology”. Içinde Imagology: The Cultural Construction and Literary Representation of National Characters : a Critical Survey, editör Joseph Theodoor Leerssen ve Manfred Beller, 3-16. Rodopi Publications, 2007.

Beller, Manfred ve Joep Leerssen: ed. Imagology: The Cultural Construction and Literary Representation of National Characters: A Critical Survey. Amsterdam: Rodopi Publications, 2007.

Berghahn, Volker R. ve Hanna Schissler: ed. Perceptions of History: International Textbook Research on Britain, Germany, and the United States. New York: Berg Publications, 1987.

Bihiku, Koço: “Instiuti i Gjuhësisë dhe i Letërsisë”. Editör Aleks Buda. Fjalori Enciklopedik Shqiptar. Tiranë: Akademia e Shkencave e RPSSH, 1985.

Bilmez, Bülent: “Amerikan Basınında Türk Kurtuluş Savaşı”. Toplumsal Tarih 92 (2001): $18-26$.

...., "Amerikan Karikatürlerinde Kurtuluş Savaş". Toplumsal Tarih 96 (2001): 29-36.

...., "Arnavutluk Ders kitaplarında Birinci Dünya Savaşı", 2011.

...., "Arnavutluk'ta Osmanlı Tarih Araştırmaları ve Tarihyazımında Modern Osmanlı". Tarih ve Toplum Yeni Yaklaşımlar 9 (2009): 157-213.

...., "Arnavut ve Türk Tarih yazımında Şemsedin Sami: Arnavut Milliyetçisi mi, yoksa Türk Milliyetçisi mi?” Toplumsal Tarih 114 (2003): 54-57. 
...., "Kosova ve Arnavutluk Tarihyazımlarında I. Meşrutiyet (1876-1878)”. Içinde Güneydoğu Avrupa ve Balkanlar'da Osmanlı Tarih Araştırmaları ve Tarih Yazıcılı̆̆ı. Seminer Bildirleri (12 Temmuz 2008), editör Halit Eren, 41-116. İstanbul: Balkan Medeniyetleri Merkezi, 2010.

...., "Modern Türkiye ve Sosyalist Arnavutluk Basınında Şemseddin Sami Frashëri İmajı". Içinde Balkanlarda İlâm Medeniyeti, II. Milletlerarası Sempozyumu Tebliğleri, 71125. İstanbul: IRCICA, 2006.

"Mythologization of an Ottoman Intellectual in the Modern Turkish and Socialist Albanian Historiographies based on 'selective perception': Sami Frashëri or Şemseddin Sami Bey”. Balkanologie. Revue d'études pluridisciplinaires VII, sayı 2 (2003): 19-46.

...., "Sami Frashëri apo Shemseddin Sami?” Çeviren Artan Puto. Përpjekja IX, sayı 18 (2003): 118-45.

...., "Skanderbeg in the Turkish Historiography: An attempt towards a critical assessment". Içinde The Living Skanderbeg. The Albanian Hero between Myth and History, editör Monica Genesin, Joachim Matzinger, ve Giancarlo Vallone, 185-222. Hamburg: Verlag Dr. Kovaç (ORBIS - Wissenschaftliche Schriften zur Landeskunde Band 16), 2010 .

...., "Şemseddin Sami Farshëri’nin Bazı Metinlerde Arnavut ve Türk 'Biz’inin İnşasına Katkıda Bulunan Otoktonluk ve Köken Mitleri”. Içinde Tanzimat ve Edebiyat ve Tanzimat, Osmanlı Istanbulu’nda Modern Edebi Kültür, editör Mehmet Fatih Uslu ve Fatih Altuğ, 387-425. İstanbul: Türkiye İş Bankası Kültür Yayınları, 2014.

...., "Şemsettin Sami ve 'Sakıncalı' bir Kitapla ilgili Tartışmalarda Milliyetçi Retorik”. Müteferrika 29, say1 1 (2006): 45-87.

...., "Tarihyazımında Kaynak Olarak Seyahatname: Evliya Çelebi'de Arnavut Bektaşileri”. Toplumsal Tarih 97 (2002): 32-42.

...., "The Place of the Eastern Question and the Turkish Independence War in the American Press (1918-1923)". Turkish Yearbook of International Relations 2000/2, say1 31 (Special Issue on Turkish-American Relations) (2000): 51-74.

Bitincka, Edlira: "Përdorimi historisë në manualet e shkollës së mesme të përdorur në vitet 1974, 1995 and 1999”. Përpjekja 18 (2003): 69-83.

Bruma, Ian ve Avishai Margalit: Garbiyatçılık - Düşmanlarının Gözünde Batı. Istanbul: YKY, 2009.

Cani, Xhyher: "Shtëpia-muze e e Migjenit". Editör Aleks Buda. Fjalori Enciklopedik Shqiptar. Tiranë: Akademia e Shkencave e RPSSH, 1985.

...., "Shtëpia-muze e Luigj Gurakuqit". Editör Aleks Buda. Fjalori Enciklopedik Shqiptar. Tiranë: Akademia e Shkencave e RPSSH, 1985. 
...., "Shtëpia-muze e Ndre Mjedës". Editör Aleks Buda. Fjalori Enciklopedik Shqiptar. Tiranë: Akademia e Shkencave e RPSSH, 1985.

Ceka, Egin: "Ndërgjegje historike. Muzeu Kombëtar dhe Muzeu i Skënderbeut si institucione të religjionit civil shqiptar të komunizmit”. Përpjekja 21 (2005): 121-47.

Chew III, William L.: "What's in a National Stereotype? An Introduction to Imagology at the Threshold of the 21st Century". Language and Intercultural Communication 6, say1 3-4 (2006): 179-87.

Çapar, Mustafa: Türkiye’de Eğitim ve Öteki Türkler. Özgür Üniversite Kitaplığı. Ankara: Maki Basın Yayın, 2006.

De Baets, Antoon: "Profile of the History Textbook Author as a Mediator between Historiography and Society”. Internationale Schulbuchforschung 16, say1 4 (1994): 515-34.

Dedi, Kleanthi ve Sokrat Mosko: "Muzeu Historik Kombëtar”. Editör Aleks Buda. Fjalori Enciklopedik Shqiptar. Tiranë: Akademia e Shkencave e RPSSH, 1985.

Dhama, Todi ve Vilson Kuri: Fjalor shpjegues i termave historike. Tiranë: 8 Nëntori, 1989.

Duka, Valentina: "Albania [Educational System and History Teaching]". Içinde Clio in the Balkans: The Politics of History Education, editör Christina Koulouri, 475-78. Thessaloniki: Center for Democracy and Reconciliation in Southeast Europe, 2002.

...., "Reflections on the Past in Albania in the 1990s". Içinde (Re)Writing History - Historiography in Southeast Europe after Socialism, editör Ulf Brunnbauer, 31-53. Münster: LIT Verlag, 2004.

Elhüseyni, Nurettin: çev. Tarihin Kötüye Kullanımı. İstanbul: Türkiye Ekonomik ve Toplumsal Tarih Vakfi, 2003.

Ferro, Marc: The Use and Abuse of History or How the Past Is Taught to Children. London; New York: Routledge, 2003.

Fickenscher, Daniel: "Das Schulwesen und die Schulbücher für die mazedonische Minderheit in Albanien". Internationale Schulbuchforschung / International Textbook Research, , Zeitschrift des Georg-Eckert-Instituts 2, say1 23 (2001): 269-75.

Foster, Stuart: "Dominant Traditions in International Textbook Research and Revision". Education Inquiry 2, say1 1 (March) (2011): 5-20.

Friedman, Norman: "İmge". Kitaplık, say1 74 (2004): 80-88.

Gasanabo, J. D.: Fostering Peaceful Co-existence Through Analysis and Revision of History Curricula and Textbooks in South East Europe. UNESCO, 2006.

Graceni, Bardhyl: "Shtëpia-muze e Kostandin Kristoforidhit". Editör Aleks Buda. Fjalori Enciklopedik Shqiptar. Tiranë: Akademia e Shkencave e RPSSH, 1985.

Güler, İbrahim: Tarihin Toplumdaki İslevi ve Öğretimi. İstanbul: Elif Kitabevi, 2005. 
Kabbani, Rana: Europe's Myths of Orient. Devise and Rule. London: Pandora Pres, 1986.

Kanar, Yüksel: Batı’nın Doğu’su (Avrupa’nın Barbarlığının Küreselleşmesi). İstanbul: Kitabevi, 2006.

Kastrati, Jup: “'Buletini Shkencor' (1958)”. Editör Aleks Buda. Fjalori Enciklopedik Shqiptar. Tiranë: Akademia e Shkencave e RPSSH, 1985.

Keyman, Fuat: Mahmut Mutman, ve Meyda Yeğenoğlu. Oryantalizm, Hegemonya ve Kültürel Fark. İstanbul: İletişim Yayınları, 1996.

Kırca, Hasan Serkan: “İngiliz Seyyah Sir Charles Fellows’un Eserlerinde Türkiye ve Türk İmajı”. Yayınlanmamış Yüksek Lisans Tezi, 2010.

Kostallari, Androkli ve Lloshi Xhevat: "Instituti i Historisë dhe i Gjuhësisë”. Editör Aleks Buda. Fjalori Enciklopedik Shqiptar. Tiranë: Akademia e Shkencave e RPSSH, 1985.

Kostovicova, Denisa: “The Portrayal of the Yoke: The Ottomans and Their Rule in the Post-1990 Albanian-Language History Textbooks". Internationale Schulbuchforschung 24, say1 2 (2002): 257-78.

Koulouri, Christina: ed. Clio in the Balkans: The Politics of History Education. Thessaloniki: Center for Democracy and Reconciliation in Southeast Europe, 2002.

...., , ed. Teaching the history of Southeastern Europe. Thessaloniki: Center for Democracy and Reconciliation in Southeast Europe, 2001.

Kula, Onur Bilge: Alman Kültüründe Türk İmgesi. C. 1. Ankara: Gündoğan Yayınları, 1992.

...., Alman Kültüründe Türk Imgesi. C. 2. Ankara: Gündoğan Yayınları, 1992.

...., Batı Düşününde Türk ve İslâm İmgesi. İstanbul: Büke Yayınları, 2002.

Leerssen, Joep: "Imagology: History and Method". Içinde Imagology: The Cultural Construction and Literary Representation of National Characters: A Critical Survey, editör Manfred Beller ve Joep Leerssen, 17-32. Amsterdam: Rodopi Publications, 2007.

Lloshi, Xhevat: ed. Academy of Sciences of Albania. Tirana: Publishing Council of the PSR of Albania, 1990.

MacRae, C. Neil, Charles Stangor ve Miles Hewstone: ed. Stereotypes and Stereotyping. New York: Guilford Press, 1996.

Marsden, William E.: The School Textbook. Geography, History and Social Studies. London \& Portland: Woburn Press, 2001.

Metani, Ira: Transforming Education: The Albanian Experience. New York: Nova Science Publishers, Inc., 2003.

Milas, Herkül: Türk Romanı ve "Öteki". Ulusal Kimlikte Yunan İmajı. İstanbul: Sabancı Üniversitesi, 2000. 
Mitchell, Thomas W. J.: Iconology: Image, Text, Ideology. Chicago: University of Chicago Press, 1986.

Myteberi, Fatmira: "Albania: Education for Peace, Stability and Democracy in Albania". Içinde Education and Media in Southeast Europe: Country Reports, editör Ulf Brunbaauer, Hannes Grandits, Siegfired Gruber, Karl Kaser, Robert Pichler, ve Christian Promitzer. Graz: Center for the Study of Balkan Societites and Cultures, 1999.

Nehring, Dieter: "Geschichtsbücher in Albanischsprachigen Gebieten Südosteuropas". Eckert. Working Papers?, say1 3 (2014).

Olsi, Jazexhi: "Depicting the Other: the Image of the Muslim and the Turk in Albania's High School Textbooks". International Journal of Turkish Studies, Madison, Wiscon$\sin$ ??, 15, sayı 1-2 (2009).

Omari, Luan ve Anastas Dodi: "Akademia e Shkencave”. Editör Aleks Buda. Fjalori Enciklopedik Shqiptar. Tiranë: Akademia e Shkencave e RPSSH, 1985.

Osmani, Shefik: “Universiteti i Tiranës 'Enver Hoxha”. Editör Aleks Buda. Fjalori Enciklopedik Shqiptar. Tiranë: Akademia e Shkencave e RPSSH, 1985.

Pajo, Erind: "Albanian Schoolsbooks in the Context of Societal Transformation: Review Notes". Içinde Clio in the Balkans: The Politics of History Education, editör Christina Koulouri, 445-61. Thessaloniki: Center for Democracy and Reconciliation in Southeast Europe, 2002.

Paksoy, A. Kadir: Ulus Devlet ve Tarih Eğitimi. Ankara: Öğretmen Dünyası, 2008.

Parla, Jale: Efendilik, Şarkiyatçılık, Kölelik. İstanbul: İletişim Yayınları, 2005.

Pichler, Robert: "Albania (in colboration with A. Ecker)". Içinde How to Construct Civil Societies? Education, Human Rights and Media in Southeast Europe: A Critical Guide, editör Ulf Brunbaauer, Hannes Grandits, Siegfired Gruber, Karl Kaser, Robert Pichler, ve Christian Promitzer. Graz: Center for the Study of Balkan Societites and Cultures, 1999.

Pingel, Falk: Ders Kitaplarının Araştırma ve Düzeltme Rehberi. İstanbul: Türkiye Ekonomik ve Toplumsal Tarih Vakfi, 2003.

Pollo, Stefanaq: "Instituti i Historisë”. Editör Aleks Buda. Fjalori Enciklopedik Shqiptar. Tiranë: Akademia e Shkencave e RPSSH, 1985.

Pricky, Gabriel: "Çek Cumhuriyeti, Macaristan, Polonya ve Slovakyadan lise ders kitapları aracılığıyla Doğu-Orta Avrupa'da Osmanlı dönemi”. Tarih ve Toplum, sayı 15 (Güz 2012).

Pulaha, Selami: "Wissenschaftliche Forschungen Über Die Osmanische Periode Des Mittelalters in Albanien (15. Jahrundert Bis Anfang Des 19. Jahrhunderts)”. Içinde Südosteuropa-Jahrbuch, 19: Die Staaten Südosteuropas und die Osmanen, editör Hans Georg Majer, 163-78. München: SelbstVerlag Südosteuropa-Gesellschaft, 1989. 
Puto, Artan: "Some Aspects of the Perception of the Ottoman period in the Albanian historiography", 2002.

Said, Edward W.: Şarkiyaţ̧ılık. Batının Şark Anlayışları. İstanbul: Metis Yayınları, 2005.

Schmitt, Oliver Jens: "Skanderbeg”. Der neue Alexander auf dem Balkan. Regensburg: Verlag Friedrich Pustet, 2009.

Solak, Ömer: Romanda Öteki / Ötekinin Romanı. Osmanlı Romanında Yanancılar ve Azınlıklar. Konya: Tablet Yayınları, 2008.

Spyrou, Spyros: "Constructing 'the Turk' as an Enemy: The Complexity of Stereotypes in Children's Everyday Worlds". South European Society and Politics 11, say1 1 (2006): 95-110.

Stojanovic, Dubravka: "Albanians and their Neighbours: the Future’s Past". Içinde Clio in the Balkans: The Politics of History Education, editör Christina Koulouri, 466-72. Thessaloniki: Center for Democracy and Reconciliation in Southeast Europe, 2002.

Stradling, Robert: 20. Yüzyıl Tarihi Nasıl Öğretilmeli. İstanbul: Türkiye Ekonomik ve Toplumsal Tarih Vakfi, 2003.

Strong, C. F.: History in the Secondary School. London: University of London Press, 1964.

Şirin, İbrahim: Osmanlı Imgeleminde Avrupa. İstanbul: Lotus, 2009.

Temo, Sotir: "Instituti i Studimeve Pedagogjike". Editör Aleks Buda. Fjalori Enciklopedik Shqiptar. Tiranë: Akademia e Shkencave e RPSSH, 1985.

Thomas, John I.: Education for Communism: School and State in the People's Republic of Albania. Stanford, California: Hoover Institution Press, 1969.

Ulağlı, Serhat: İmgebilim “Öteki”nin Bilimine Giriş. Ankara: Sinemis Yayınları, 2006.

Xhyher, Cani: “Shtëpia-muze e 'Dega e Lidhjes Shqiptare e Shkodrës”. Editör Aleks Buda. Fjalori Enciklopedik Shqiptar. Tiranë: Akademia e Shkencave e RPSSH, 1985.

Yıldız, Süleyman: “Türk ve Alman Toplumlarında Kültürel İlişkiler, İmgeler ve Medya”. Milli Folklor 18 (2006): 37-46.

Yücel, Müslüm: Osmanlı-Türk Romanında Kürt İmgesi. İstanbul: Agora, 2011.

Zunıć, Mırna: “Hırvatistan'da Tarih Ders Kitaplarında Osmanlı İmajı”. Yüksek Lisans Tezi, Yıldız Teknik Üniversitesi, Siyaset Bilimi ve Uluslararası İlişkiler Ana Bilim Dalı, 2008. 


\section{İncelenen Ders Kitapları:}

6. sınıf DK = Treska, Tomi \& Dërguti, Menduh 2011 [2005]: Historia (Për klasën e 6-të të shkollës 9-Vjeçare), Botime Shkollore Albas.

7. sınıf DK = Dërguti, Menduh \& Treska, Tomi 2011 [2006]: Historia (Për klasën e 7-të të shkollës 9-Vjeçare), Botime Shkollore Albas.

8. sınıf DK = Dërguti, Menduh \& Treska, Tomi 2011 [2007]: Historia (Për klasën e 8-të të shkollës 9-Vję̧are), Botime Shkollore Albas.

9. sınıf DK = Dërguti, Menduh; Boçi, Sonila \& Dushku, Ledia 2011 [2009]: Historia (Për klasën e 9-të të shkollës 9-Vjeçare), Botime Shkollore Albas.

11. sınıf DK = Dërguti, Menduh \& Treska, Tomi 2011 [2010]: Historia e qytetërimit botëror, Botime Shkollore Albas.

12. sınıf DK = Dërguti, Menduh; Dushku, Ledia; Duka, Ferit \& Doçi, Sonila 2011 [2005]: Historia e shqiptarëve (Për klasën e 12-të shkollës mesme), Botime Shkollore Albas. 